\title{
Variability of aerosol, gaseous pollutants and meteorological characteristics associated with changes in air mass origin at the SW Atlantic coast of Iberia
}

\author{
J.-M. Diesch ${ }^{1}$, F. Drewnick ${ }^{1}$, S. R. Zorn ${ }^{1,{ }^{*}}$, S.-L. von der Weiden-Reinmüller ${ }^{1}$, M. Martinez ${ }^{2}$, and S. Borrmann ${ }^{1,3}$ \\ ${ }^{1}$ Particle Chemistry Department, Max Planck Institute for Chemistry, Mainz, Germany \\ ${ }^{2}$ Atmospheric Chemistry Department, Max Planck Institute for Chemistry, Mainz, Germany \\ ${ }^{3}$ Institute for Atmospheric Physics, Johannes Gutenberg University Mainz, Mainz, Germany \\ *now at: AeroMegt GmbH, Hilden, Germany
}

Correspondence to: J.-M. Diesch (j.diesch@mpic.de), F. Drewnick (frank.drewnick@mpic.de)

Received: 28 September 2011 - Published in Atmos. Chem. Phys. Discuss.: 2 December 2011

Revised: 24 February 2012 - Accepted: 29 March 2012 - Published: 25 April 2012

\begin{abstract}
Measurements of the ambient aerosol were performed at the Southern coast of Spain, within the framework of the DOMINO (Diel Oxidant Mechanisms In relation to Nitrogen Oxides) project. The field campaign took place from 20 November until 9 December 2008 at the atmospheric research station "El Arenosillo" $\left(37^{\circ} 5^{\prime} 47.76^{\prime \prime} \mathrm{N}\right.$, $\left.6^{\circ} 44^{\prime} 6.94^{\prime \prime} \mathrm{W}\right)$. As the monitoring station is located at the interface between a natural park, industrial cities (Huelva, Seville) and the Atlantic Ocean, a variety of physical and chemical parameters of aerosols and gas phase could be characterized in dependency on the origin of air masses. Backwards trajectories were examined and compared with local meteorology to classify characteristic air mass types for several source regions. Aerosol number and mass as well as polycyclic aromatic hydrocarbons and black carbon concentrations were measured in $\mathrm{PM}_{1}$ and size distributions were registered covering a size range from $7 \mathrm{~nm}$ up to $32 \mu \mathrm{m}$. The chemical composition of the non-refractory submicron aerosol $\left(\mathrm{NR}-\mathrm{PM}_{1}\right)$ was measured by means of an Aerosol Mass Spectrometer (Aerodyne HR-ToF-AMS). Gas phase analyzers monitored various trace gases $\left(\mathrm{O}_{3}, \mathrm{SO}_{2}, \mathrm{NO}, \mathrm{NO}_{2}\right.$, $\mathrm{CO}_{2}$ ) and a weather station provided meteorological parameters.

Lowest average submicron particle mass and number concentrations were found in air masses arriving from the Atlantic Ocean with values around $2 \mu \mathrm{g} \mathrm{m}^{-3}$ and $1000 \mathrm{~cm}^{-3}$. These mass concentrations were about two to four times lower than the values recorded in air masses of continental
\end{abstract}

and urban origins. For some species $\mathrm{PM}_{1}$-fractions in marine air were significantly larger than in air masses originating from Huelva, a closely located city with extensive industrial activities. The largest fraction of sulfate (54\%) was detected in marine air masses and was to a high degree not neutralized. In addition, small concentrations of methanesulfonic acid (MSA), a product of biogenic dimethyl sulfate (DMS) emissions, could be identified in the particle phase.

In all air masses passing the continent the organic aerosol

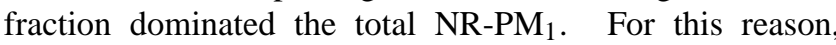
using Positive Matrix Factorization (PMF) four organic aerosol (OA) classes that can be associated with various aerosol sources and components were identified: a highlyoxygenated $\mathrm{OA}$ is the major component $(43 \% \mathrm{OA})$ while semi-volatile OA accounts for $23 \%$. A hydrocarbon-like OA mainly resulting from industries, traffic and shipping emissions as well as particles from wood burning emissions also contribute to total OA and depend on the air mass origin.

A significant variability of ozone was observed that depends on the impact of different air mass types and solar radiation.

\section{Introduction}

Studying tropospheric aerosols is becoming increasingly important as they influence the Earth's climate (IPCC, 2007), continental, urban and marine ecosystems and visibility 
(Querol et al., 2009). In addition they can have a significant influence on human health (Pope and Dockery, 2006). To study the influence of natural and anthropogenic pollutants emitted by local and regional sources, measurement campaigns at remote sites are required where the complex mixture of components in the atmosphere can be observed. This mixture depends on the various source regions influencing the measurement site as well as their distance, since chemical and physical processing takes place in an air mass during transport. In addition, particularly in Southern Europe, the season plays an important role. In the summer months African dust outbreaks, re-circulation of air masses, strong photochemistry and long range transport from NW Europe or Western Iberia (Sanchez de la Campa et al., 2007; Pey et al., 2008) affect the atmospheric composition and levels. The SW of Spain lies next to the Atlantic Ocean and the Strait of Gibraltar, a major ship route. There are several large towns and cities, the largest of them Seville, important ports like the one of Huelva, as well as large agricultural plantations and forests.

The air quality close to the heavily industrialized area around the city of Huelva is significantly degraded at times. Epidemiological studies (CSIC, 2002) as well as the distribution of cancer incidents in Spain (Benach et al., 2003) suggest that certain kinds of cancers (e.g. lung cancer) occur in this region at an elevated rate. Therefore, a number of studies were performed, mainly in and around Huelva to evaluate the impact of industrial emissions and their characterization in terms of the chemical composition and potential origin (Fernández-Camacho et al., 2010b; de la Rosa et al., 2010; Perez-Lopez et al., 2010; de la Campa et al., 2011; Toledano et al., 2009). In addition, the interaction of high solar radiation levels as they occur in Andalusia together with elevated anthropogenic and natural ozone precursor emissions lead to enhanced photochemical ozone production that can be measured downwind of industrialized regions, where the ozone precursor substances are emitted (Adame et al., 2008, 2010a, b).

So far no comprehensive studies investigating the chemical composition of aerosol particles in conjunction with measurements of a variety of trace gases were conducted in Southern Spain. The aim of this study is to present a detailed investigation of the variability of aerosol, trace gas characteristics and meteorological conditions depending on continental, urban and marine sources surrounding the measurement site in "El Arenosillo". Backwards trajectories were calculated and compared to local meteorology to classify different air mass categories. The non-refractory submicron aerosol composition was determined depending on the air mass categories. The sulfate fraction was further investigated regarding aerosol acidity for the individual air mass types. A focus is also on organic components of the aerosol, their sources and variations. Furthermore, the dependence of the diurnal ozone variation associated with meteorological conditions and different air masses was analyzed.

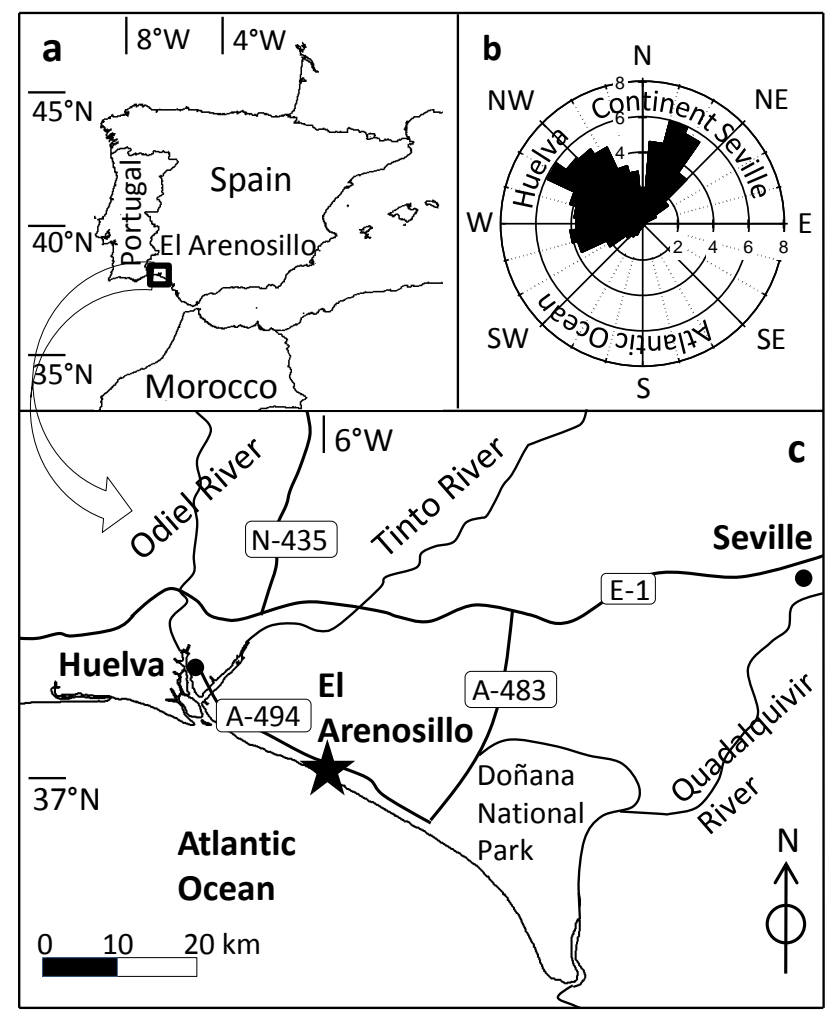

Fig. 1. Map of Spain (a) showing the location of the field measurements (c) and an angular histogram of the wind directions recorded during the campaign (b).

\section{Overview of the 2008 DOMINO campaign}

The 2008 DOMINO (Diel Oxidant Mechanisms In relation to Nitrogen Oxides) research campaign took place from 20 November until 9 December at the atmospheric research station "El Arenosillo" (37 $\left.7^{\circ} 47.76^{\prime \prime} \mathrm{N}, 6^{\circ} 44^{\prime} 6.94^{\prime \prime} \mathrm{W}\right)$ in the southwest of Spain (Fig. 1a), operated by the INTA (National Institute for Aerospace Technology). The main objective of the campaign was to characterize the oxidative capacity of the troposphere. For this reason, the focus was to study the atmospheric oxidation chemistry, to compare the radical and nighttime chemistry and to characterize the selfcleaning efficiency of the atmosphere in different air mass types. Our contribution to this project was the investigation of the aerosol particle chemistry, composition, formation and transformation processes. Therefore, we measured a large number of atmospheric parameters simultaneously.

The "El Arenosillo" research station lies within a Protected Natural Area in between 3 very different source regions: the Atlantic Ocean, the town of Huelva $(20 \mathrm{~km}$ distance) and the nearby National Park of Doñana. The Atlantic Ocean itself has relatively low levels of pollutants, however there are shipping emissions from heavy ship traffic in the Strait of Gibraltar (Pey et al., 2008). Huelva is a highly industrialized town with three large chemical estates 
where fertilizer production industries, petrochemical industries, ammonia and urea industries as well as paper production industries are situated (Carretero et al., 2005; Alastuey et al., 2006; Querol et al., 2002, 2004; Fernández-Camacho et al., 2010a). The nearby National Park of Doñana on the other hand is a Nature Preserve Park with a large variety of ecosystems and a unique biodiversity (de la Campa et al., 2009). Situated in the west of the Guadalquivir River, it is a UNESCO Biosphere Reserve and Heritage of Mankind consisting of marshlands, pine forests, preserves and moving sand dunes. Beyond it at $70 \mathrm{~km}$ distance from the site lies the city of Seville, the capital of Andalusia (population: 704000 ). However it is less industrialized than Huelva (population: 149000) which is located at the southwestern end of the Andalusian region and is surrounded by the rivers Odiel and Tinto and the Atlantic Ocean (Fig. 1c). The predominant wind directions at the station during the time the study took place were WSW, NW and NNE transporting air from Seville, Huelva, the Continent and the Atlantic Ocean to the measurement site (Fig. 1b).

In order to study the variability of the particle loading, composition, size distributions as well as trace gas and meteorological parameters in different types of air masses whose origin is well defined, the campaign was conducted in winter. This offers the advantage to achieve a better understanding of the characteristics, sources and processes, as typical summer features in this part of Southern Europe are reduced: enhanced photochemistry or recirculation periods that typically occur in spring and summer seasons in this part of Southern Europe (Pey et al., 2008) would contribute to a more complex study scenario.

In the beginning of the campaign from 20 November until 3 December fair weather conditions with sunny days and clear skies prevailed. Therefore, a stable nocturnal boundary layer existed and low altitude emissions for example from Huelva were accumulated and measured at elevated concentrations. Only on two nights (28-29 and 29-30 November) short precipitation periods occurred which did not change the atmospheric composition significantly as the wind originated from the marine source region and concentrations remained as low as before. During the last 6 days of the campaign (3-9 December), it was cloudy with nearly constant temperature, relative humidity and air pressure near ground.

\subsection{Setup for ground based measurements of aerosol, gas phase species and meteorology}

\subsubsection{Key instrumentation}

Measurements of the ambient aerosol and several trace gas concentrations were performed using MoLa, a mobile platform for aerosol research (Drewnick et al., 2012). During this campaign physical aerosol particle properties in $\mathrm{PM}_{1}$ were detected by the ultrafine water-based Condensation Particle Counter in the $5 \mathrm{~nm}$ to $3 \mu \mathrm{m}$ size range (CPC 3786, TSI,
Inc.) as well as the Filter Dynamics Measurement System Tapered Element Oscillating Microbalance (FDMS-TEOM, Rupprecht \& Patashnick Co., Inc.) (see Table 1). For particle size information, a Fast Mobility Particle Sizer (FMPS 3091, TSI, Inc.), an Aerodynamic Particle Sizer (APS 3321, TSI, Inc.) as well as an Optical Particle Counter (OPC 1.109 , Grimm) were used to cover a particle size range from $7 \mathrm{~nm}$ until $32 \mu \mathrm{m}$. The chemical composition of the non-refractory (NR) aerosol in the submicron range was measured by means of a High-Resolution Time-of-Flight Aerosol Mass Spectrometer using the "V-mode" (HR-ToFAMS, Aerodyne Res., Inc.). The black carbon concentration in $\mathrm{PM}_{1}$ was determined by a Multi Angle Absorption Photometer (MAAP, Thermo E.C.) and polycyclic aromatic hydrocarbons on particles were appointed by the PAH-Monitor (PAS 2000, EcoChem. Analytics). MoLa is also equipped with two instruments to detect various trace gases. An Airpointer (Recordum $\mathrm{GmbH}$ ) measures the gas phase species $\mathrm{SO}_{2}, \mathrm{CO}, \mathrm{NO}, \mathrm{NO}_{2}$ and $\mathrm{O}_{3} . \mathrm{CO}_{2}$ and $\mathrm{H}_{2} \mathrm{O}$ were monitored using a LICOR 840 gas analyzer (LI-COR, Inc.). A weather station (WXT 510, Vaisala) provided the most important weather parameters, such as ambient temperature, relative humidity, air pressure, wind speed, wind direction and rain intensity.

\subsubsection{Sampling setup}

During the field campaign the roof inlet of MoLa, which is normally available for stationary measurements, was used. Next to the roof inlet an extendable mast with the meteorological station was fixed, both for measurements in $10 \mathrm{~m}$ height. Short branches were used to connect several instruments with the main inlet system. The sampling line is optimized for a flow rate of about $901 \mathrm{~min}^{-1}$ and therefore a pump with flow control was used for regulating this flow independent of the set of instruments operating. The inlet was optimized and characterized for transport losses and sampling artifacts (von der Weiden et al., 2009). One of the main characteristics is the occurring aerosol particle loss. Table 1 contains particle loss information for all instruments calculated using the Particle Loss Calculator (von der Weiden et al., 2009). While particle losses have a maximum of $45 \%$ for $20 \mu \mathrm{m}$ particles for the APS, for all other instruments used during the campaign maximum particle losses are below $25 \%$. The respective losses are relatively small in the size range where the majority of relevant data for this work is collected: in the size range from $30 \mathrm{~nm}$ to $2 \mu \mathrm{m}$ calculated particle losses are below $8 \%$ (without regarding the AMS: $<3 \%$ ). Therefore the occurring particle loss can be neglected since they do not influence the measurement results significantly and the ambient aerosol was measured mostly unbiased in this range.

Transport times through the sampling line differ slightly for the individual instruments, so the sampling and measurement times are not identical. Therefore the time stamp for 
Table 1. Summary of measured quantities, size ranges and the corresponding particle losses, sampling time delays and detection limits for the instruments implemented in the mobile laboratory (MoLa). Particle losses within the given size range boundaries are lower than those provided here; therefore the given losses are upper limits.

\begin{tabular}{|c|c|c|c|c|}
\hline $\begin{array}{l}\text { Measurement } \\
\text { Instrument }\end{array}$ & Measured Quantity & $\begin{array}{l}\text { Size Range/ } \\
\text { (Particle losses) }\end{array}$ & $\begin{array}{l}\text { Sampling } \\
\text { Delay }\end{array}$ & $\begin{array}{l}\text { Detection Limits/ } \\
\text { Accuracy }\end{array}$ \\
\hline \multicolumn{5}{|l|}{ AMS } \\
\hline $\begin{array}{l}\text { Aerosol Mass } \\
\text { Spectrometer }\end{array}$ & $\begin{array}{l}\text { size-resolved Aerosol } \\
\text { Chemical Composition }\end{array}$ & $\begin{array}{l}40 \mathrm{~nm}(6 \%)- \\
600 \mathrm{~nm}(2 \%) \\
\text { (vacuum } \\
\text { aerodynamic } \\
\text { diameter) }\end{array}$ & $43 \mathrm{~s}$ & $\begin{array}{l}\text { sulfate: } 0.04 \mu \mathrm{g} \mathrm{m}^{-3} \\
\text { nitrate: } 0.02 \mu \mathrm{g} \mathrm{m}^{-3} \\
\text { ammonium: } 0.05 \mu \mathrm{g} \mathrm{m}^{-3} \\
\text { chloride: } 0.02 \mu \mathrm{g} \mathrm{m}^{-3} \\
\text { organics: } 0.09 \mu \mathrm{g} \mathrm{m}^{-3}\end{array}$ \\
\hline \multicolumn{5}{|l|}{ MAAP } \\
\hline $\begin{array}{l}\text { Multi Angle Absorp- } \\
\text { tion Photometer }\end{array}$ & $\begin{array}{l}\text { Black Carbon Particle } \\
\text { Mass Concentration }\end{array}$ & $\begin{array}{l}10 \mathrm{~nm}(4 \%)- \\
1 \mu \mathrm{m}(0.2 \%)\end{array}$ & $7 \mathrm{~s}$ & $0.1 \mu \mathrm{g} \mathrm{m}^{-3}$ \\
\hline \multicolumn{5}{|l|}{ PAH-Sensor } \\
\hline $\begin{array}{l}\text { Polycyclic Aromatic } \\
\text { Hydrocarbons Sensor }\end{array}$ & $\begin{array}{l}\text { total PAH } \\
\text { Mass Concentration }\end{array}$ & $\begin{array}{l}10 \mathrm{~nm}(11 \%)- \\
1 \mu \mathrm{m}(0.3 \%)\end{array}$ & $8 \mathrm{~s}$ & $1 \mathrm{ng} \mathrm{m}^{-3}$ \\
\hline \multicolumn{5}{|l|}{ CPC } \\
\hline $\begin{array}{l}\text { Condensation Particle } \\
\text { Counter }\end{array}$ & $\begin{array}{l}\text { Particle } \\
\text { Number Concentration }\end{array}$ & $\begin{array}{l}5 \mathrm{~nm}(25 \%)- \\
3 \mu \mathrm{m}(0.8)\end{array}$ & $7 \mathrm{~s}$ & N/A \\
\hline \multicolumn{5}{|l|}{ TEOM } \\
\hline $\begin{array}{l}\text { Tapered Element } \\
\text { Oscillating } \\
\text { Microbalance }\end{array}$ & $\begin{array}{l}\text { Particle } \\
\text { Mass Concentration }\left(\mathrm{PM}_{1}\right)\end{array}$ & $<1 \mu \mathrm{m}(0.5-9 \%)$ & $9 \mathrm{~s}$ & $2.5 \mu \mathrm{g} \mathrm{m}^{-3}$ \\
\hline \multicolumn{5}{|l|}{ FMPS } \\
\hline $\begin{array}{l}\text { Fast Mobility Particle } \\
\text { Sizer }\end{array}$ & $\begin{array}{l}\text { Particle Size Distribution } \\
\text { based on Electrical Mobility }\end{array}$ & $\begin{array}{l}7 \mathrm{~nm}(9 \%)- \\
523 \mathrm{~nm}(0.1 \%) \\
\left(D_{\mathrm{mob}}\right)\end{array}$ & $7 \mathrm{~s}$ & N/A \\
\hline \multicolumn{5}{|l|}{ APS } \\
\hline $\begin{array}{l}\text { Aerodynamic Particle } \\
\text { Sizer }\end{array}$ & $\begin{array}{l}\text { Particle Size Distribution } \\
\text { based on Aerodynamic Sizing }\end{array}$ & $\begin{array}{l}0.37 \mu \mathrm{m}(0.1 \%)- \\
20 \mu \mathrm{m}(45 \%) \\
\left(D_{\text {aero }}\right)\end{array}$ & $7 \mathrm{~s}$ & N/A \\
\hline \multicolumn{5}{|l|}{ OPC } \\
\hline $\begin{array}{l}\text { Optical Particle } \\
\text { Counter }\end{array}$ & $\begin{array}{l}\text { Particle Size Distribution } \\
\text { based on Light Scattering } \\
\text { Cross Section }\end{array}$ & $\begin{array}{l}0.25 \mu \mathrm{m}(0.05 \%)- \\
32 \mu \mathrm{m}(0.002 \%) \\
\left(D_{\text {opt }}\right)\end{array}$ & $8 \mathrm{~s}$ & N/A \\
\hline \multicolumn{5}{|l|}{ Airpointer } \\
\hline & $\begin{array}{l}\mathrm{O}_{3}, \mathrm{SO}_{2}, \mathrm{CO} \text { and } \mathrm{NO}, \mathrm{NO}_{2} \\
\text { Mixing Ratio }\end{array}$ & N/A & $6 \mathrm{~s}$ & $\begin{array}{l}\mathrm{O}_{3}:<1.0 \mathrm{nmol} \mathrm{mol}^{-1} \\
\mathrm{SO}_{2}:<1.0 \mathrm{nmol} \mathrm{mol}^{-1} \\
\mathrm{CO}:<0.08 \mu \mathrm{mol} \mathrm{mol}^{-1} \\
\mathrm{NO}_{\mathrm{x}}:<2.0 \mathrm{nmol} \mathrm{mol}^{-1}\end{array}$ \\
\hline \multicolumn{5}{|l|}{ LICOR LI840 } \\
\hline & $\begin{array}{l}\mathrm{CO}_{2} \text { and } \mathrm{H}_{2} \mathrm{O} \\
\text { Mixing Ratio }\end{array}$ & N/A & $8 \mathrm{~s}$ & $\begin{array}{l}\mathrm{CO}_{2}: 1 \mu \mathrm{mol} \mathrm{mol}^{-1} \\
\text { (accuracy) } \\
\mathrm{H}_{2} \mathrm{O}: 0.01 \mathrm{pmol} \mathrm{mol}^{-1}\end{array}$ \\
\hline \multicolumn{5}{|l|}{ Met. Station } \\
\hline & $\begin{array}{l}\text { Wind speed and Direction, } \\
\text { Temperature, RH, } \\
\text { Rain Intensity, Pressure }\end{array}$ & N/A & $0 \mathrm{~s}$ & N/A \\
\hline
\end{tabular}


each instrument has to be corrected depending on the residence time of the aerosol in the tube system. The calculated delays for all instruments were subtracted from the time stamps to get the correct sampling time. The sampling delays for the individual instruments are also presented in Table 1. The time resolution used for this analysis was $1 \mathrm{~min}$ for all instruments beside the TEOM which generated $15 \mathrm{~min}$ data.

\subsubsection{Quality assurance for aerosol chemical composition measurements}

For data quality assurance a variety of calibrations of the AMS were performed before and during the campaign. A particle Time-of-Flight calibration was accomplished prior to the campaign, used to convert particle flight times into the corresponding particle diameters. For determination of the instrument background and several distinct instrument parameters, measurements using a high-efficiency particulate air (HEPA) filter as well as a calibration of the Ionization efficiency (IE) of the ion source were conducted once a week. The sensitivity of the detector was monitored permanently and calibrated frequently as well.

A collection efficiency (CE) factor (Huffman et al., 2005) has to be determined to account for the fraction of particles that are not detected as they bounce off the vaporizer before evaporation and to correct for incomplete transmission of particles through the inlet of the instrument. Usually this factor is determined by comparing AMS measurements with results from other instruments or filter measurements. This factor usually ranges between 0.5 (for $50 \%$ particle loss) and 1 (no bounce) and depends mainly on the measurement conditions, for example, relative humidity or particle composition. For the DOMINO campaign, a CE factor of 0.5 for the AMS mass concentrations (organics, sulfate, nitrate, ammonium and chloride) was used. When using this typical CE factor, the time series of the ToF-AMS mass concentrations summed with the MAAP black carbon mass concentrations show a good agreement with TEOM $\mathrm{PM}_{1}$ mass concentrations (ratio $\mathrm{PM}_{\mathrm{AMS}+\mathrm{MAAP}} / \mathrm{PM}_{\mathrm{TEOM}}=0.97, R^{2}=0.6$ ).

During normal operation, the AMS collected averaged high resolution mass spectra and species-resolved size distributions by alternating through the related operation modes, spending $50 \%$ of the sampling time in each mode. The detection limits (LOD, Table 1) for each species were evaluated on the basis of the method described by Drewnick et al. (2009). They are defined as

$\mathrm{LOD}=3 \cdot \sqrt{2} \cdot \sigma(I)$

with $\sigma(I)$ the standard deviation of the background signals of the respective species.

\subsection{Back trajectories and air mass classification}

To classify different source regions that are reflected in the aerosol and trace gas composition of the air arriving at the measurement site, $48 \mathrm{~h}$ back trajectories at $10 \mathrm{~m}$ arrival height above ground level were calculated for every $2 \mathrm{~h}$ during the whole campaign using the HYSPLIT (HYbrid Single Particle Lagrangian Integrated Trajectory) model (Draxler and Rolph, 2003). To analyze the measured data of chemical and physical aerosol particle properties as well as gas phase parameters that are associated with different source regions, the whole dataset was divided according to back trajectories that correspond to similar air mass histories. For this assignment we assume that the respective data, one hour before the arrival time and one hour thereafter, "belong" to each trajectory and associate these data in the further analysis with the source region defined by the trajectory. Figure 2 shows a map including back trajectories classified into 6 air mass categories based on air mass origins and pathways. The resulting air mass categories with the corresponding angles of the limiting trajectory arrival directions as well as the measurement time in percent of the entire measurement period are:

$$
\begin{aligned}
& \text { - "Seville" }\left(65-82^{\circ}, 6 \%\right) \\
& \text { - "Continental" }\left(340-65^{\circ}, 15 \%\right) \\
& \text { - "Portugal + Huelva" }\left(310-328^{\circ}, 3 \%\right) \\
& \text { - "Marine + Huelva" }\left(285-310^{\circ}, 18 \%\right) \\
& \text { - "Portugal + Marine" }\left(265-285^{\circ}, 15 \%\right) \\
& \text { - "Marine" }\left(140-265^{\circ}, 6 \%\right) .
\end{aligned}
$$

To be classified as "Seville", calculated back trajectories had to cross Seville (latitude and longitude for "Seville" category borders: $37^{\circ} 16^{\prime} 11^{\prime \prime} \mathrm{N}, 5^{\circ} 54^{\prime} 33^{\prime \prime} \mathrm{W}$ and $37^{\circ} 24^{\prime} 55^{\prime \prime} \mathrm{N}$, $6^{\circ} 5^{\prime} 1^{\prime \prime} \mathrm{W}$ ) before approaching the measurement site. Air masses labeled as "Continental" contain air transported from Spanish inland areas over pine and eucalyptus forests to the station. While "Portugal + Huelva" trajectories mainly travel over Portugal before passing Huelva and then the site; trajectories corresponding to "Marine + Huelva" firstly travelled over the Atlantic Ocean (Huelva category borders: $37^{\circ} 19^{\prime} 1^{\prime \prime} \mathrm{N}, 6^{\circ} 50^{\prime} 36^{\prime \prime} \mathrm{W}$ and the coastline). In contrast to "Portugal + Huelva" air masses with trajectories spreading preferentially over the northern part of Huelva city, "Marine + Huelva" trajectories extend over the whole area of the city. Finally, the fifth ("Portugal + Marine") and sixth ("Marine") category include marine influenced air masses with the difference that "Portugal + Marine" trajectories also passed Portugal. For each air mass type aerosol as well as gas phase and meteorological parameters were analyzed separately. In total, $63 \%$ of the measured data were considered in our examinations. The remaining data are associated with trajectories that passed along the boundaries of the categories and cannot reliably be associated with any of the six categories.

HYSPLIT is intended for transport processes on larger spatial scales due to its relatively low grid resolution. Especially for lower trajectory altitudes, the model suffers 


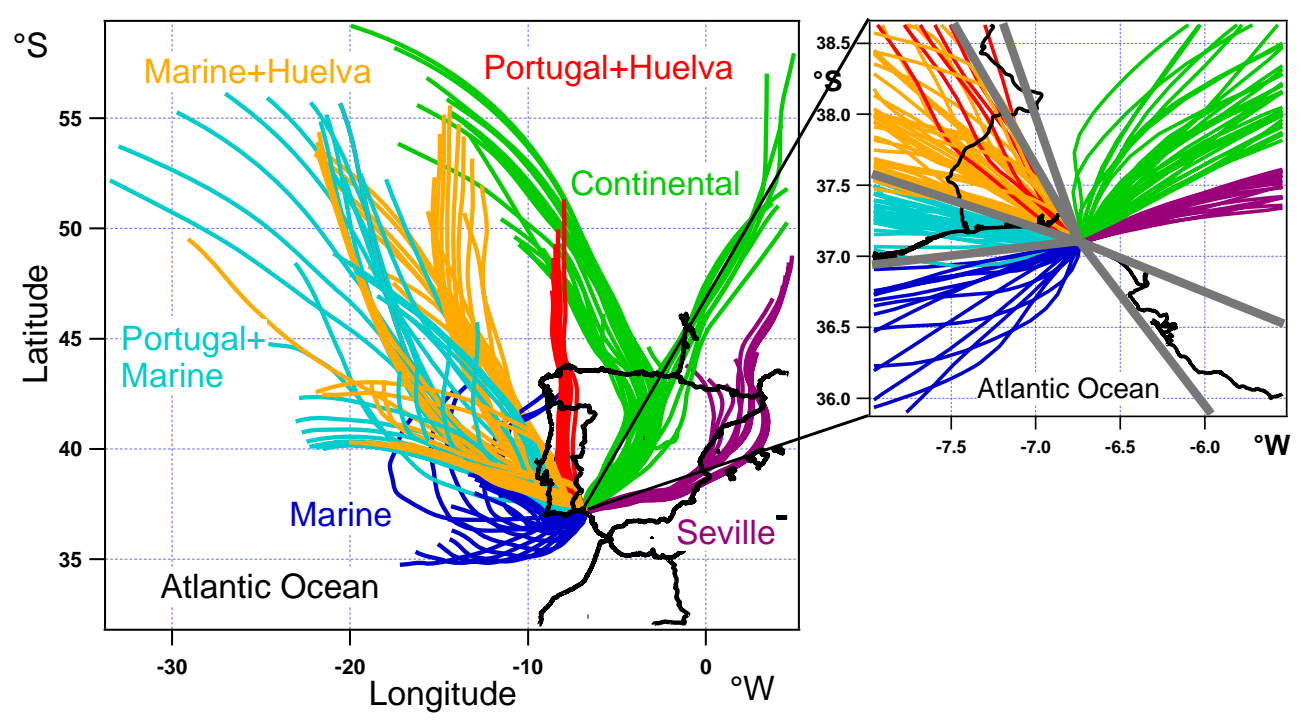

Fig. 2. On the left side, a map of the Iberian Peninsula is shown including $48 \mathrm{~h}$ backwards trajectories calculated for every $2 \mathrm{~h}$ using HYSPLIT. The zoom-in at the right shows the transport direction of the classified air mass types at the measurement site. 6 air mass categories corresponding to different source regions were separated: "Seville" (purple), "Continental" (green), "Portugal + Huelva" (red), "Marine + Huelva" (orange), "Portugal + Marine" (light blue), "Marine" (blue).

from severe limitations. Therefore, under the influence of mesoscale processes, HYSPLIT is not able to reproduce local meteorology adequately. However, during the DOMINO campaign synoptic conditions dominated also regional transport which can therefore be reproduced sufficiently accurate down to the lower boundary layer by HYSPLIT calculations as was shown by thorough sensitivity analyses and comparison to measurement data (J. A. Adame Carnero, personal communication, 2012).

As a second approach for the identification of the air mass origin, local meteorology was used and measured at the sampling site. Here the whole measured data set was divided into different sectors according to the wind direction registered by the meteorological station in $10 \mathrm{~m}$ height. In order to avoid associating stagnant air masses with potential contamination from local sources with individual source sectors, all data measured during times with wind speeds below $1 \mathrm{~m} \mathrm{~s}^{-1}$ were not used for further processing. Hereafter, 3 different source regions associated with individual wind directions were identified, called "Continental", "Urban" and "Marine".

In Fig. 3 locally measured wind direction data were compared for both classification methods. The three different wind direction ranges of the "Continental" $\left(340-110^{\circ}\right)$, "Urban" $\left(285-330^{\circ}\right)$ and "Marine" (140-265 $)$ sectors are shown as grey shaded areas. Red colored box plots reflect the local wind directions measured during the arrival times of the back trajectories associated with various air mass categories. For the "Seville", "Continental", "Marine + Huelva" and "Marine" air mass categories, the measured wind directions agree quite well with the wind sectors associated with the same source regions. Contrary, measured wind direc-

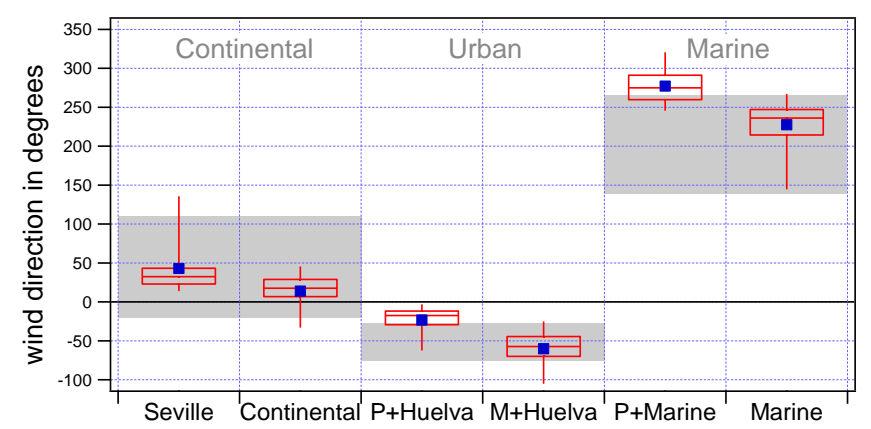

Fig. 3. Comparison of wind directions associated with the classified air mass categories (HYSPLIT) with wind direction ranges used for the identification of the three sectors. The wind directions associated with the HYSPLIT air mass categories are presented as box plots (blue marker: mean, box: $25-75 \%$ percentiles with median, whiskers: $5 \%$ and $95 \%$ percentiles) while the wind direction ranges are shown as grey shaded area.

tions of the "Portugal + Marine" air masses are not located within any of the wind direction ranges, because this air mass type could not be separated using the wind direction method, since a gap had to be selected between land (Huelva) and marine influenced air masses. For the "Portugal + Huelva" and "Marine + Huelva" air mass categories the directions of the trajectories differ slightly but systematically from locally measured wind directions, because registered wind directions are influenced by the land-sea-circulation. This effect results in wind directions measured at the site, which was located directly at the shore, oriented further south - compared to the direction of the trajectories - during daytime while during the night they are rotated more towards the north. 


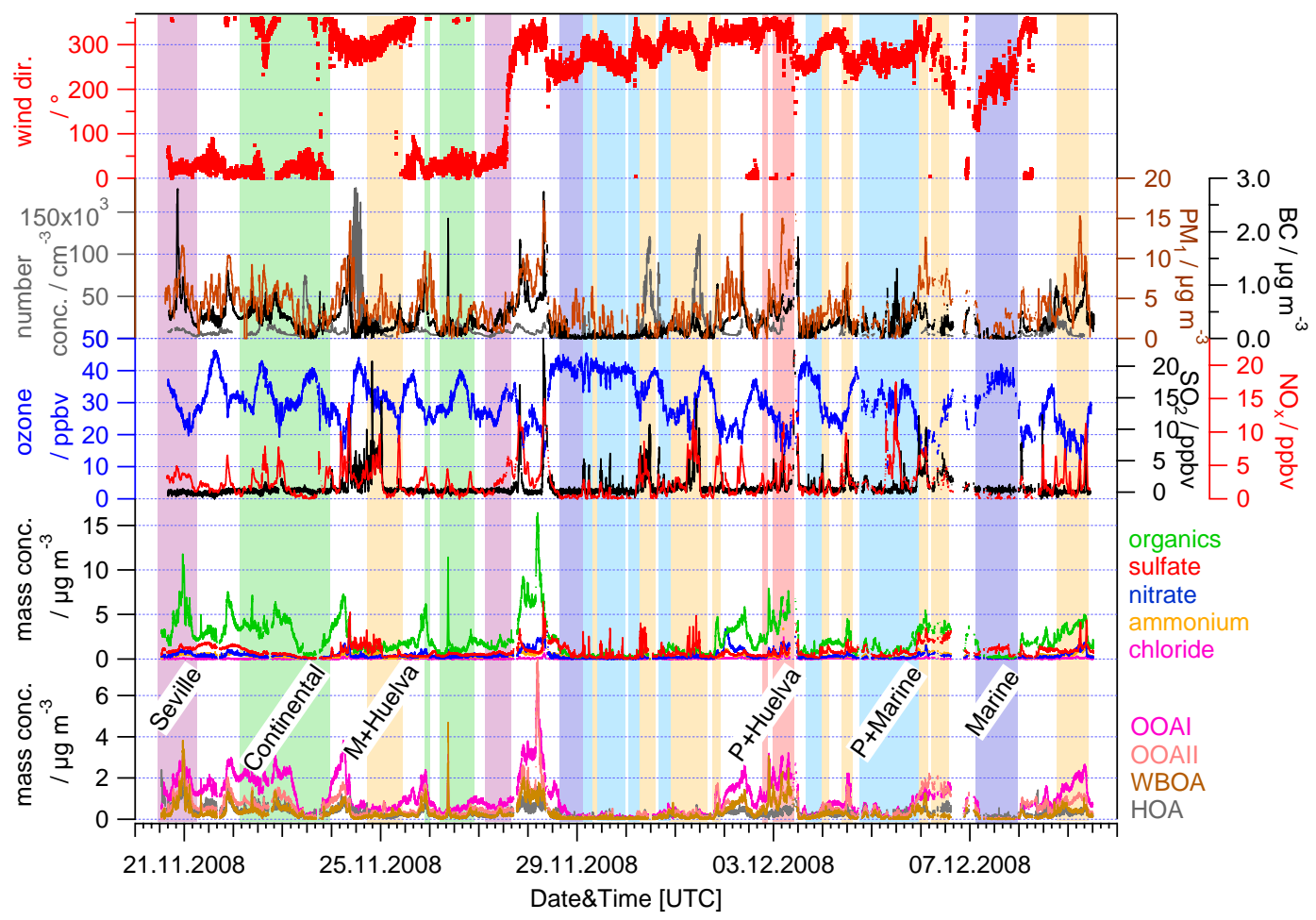

Fig. 4. Time series of several parameters (wind direction (red), number (grey) and $\mathrm{PM}_{1}$ mass (brown) concentrations, black carbon (black), ozone (blue), sulfur dioxide $\left(\mathrm{SO}_{2}\right.$, black), nitrogen oxide $\left(\mathrm{NO}_{\mathrm{x}}\right.$, red), AMS species (organics (green), sulfate (red), nitrate (blue), ammonium (orange), chloride (purple), OOAI (purple), OOAII (salmon), WBOA (brown), HOA (grey)) measured during the DOMINO campaign and discussed in the paper. The classified air mass categories are indicated as shaded areas behind the traces ("Seville" (purple), "Continental" (green), "Portugal + Huelva" (red), "Marine + Huelva" (orange), "Portugal + Marine" (light blue), "Marine" (blue)).

In summary, the classification of air mass types made on the basis of back trajectories is more robust than that based on wind directions. HYSPLIT enables a more exact apportionment of air masses as it considers not only local conditions but also regional and long-range transport influences. However, both methods of associating measurement data to source regions provide similar results when regarding both "Huelva"-related air mass categories as "Urban" and the "Seville" and "Continental" air mass categories as "Continental". Although very similar results are obtained with both methods, the use of HYSPLIT to identify air masses gives the possibility to separate the data into additional air mass types that cannot be identified on the basis of wind directions alone (e.g. "Seville").

In Fig. 4 time series for several of the measured parameters that are discussed below are shown for the whole campaign. The time intervals associated with the classified air mass categories are indicated as shaded areas in different colors. As shown in this figure, for the "Continental", "Marine + Huelva" and "Portugal + Marine" air mass categories the air mass origin persisted over relatively long periods on several days. Therefore, the influx from other source regions into these air masses is very unlikely. On the other hand, the "Portugal + Huelva" category was registered only for short time intervals and only on a single day. Therefore, for this air mass category, influx from other source regions by recirculation of air masses in varying wind fields cannot be excluded, even though the back trajectories do not show any evidence for this effect. The "Seville" category was measured during two approximately half-day long periods on two different days. Significant differences in the measured parameters have been found for the two time intervals because different phases of new particle formation events have been probed during these times. However, even though mixing with "Continental" air masses is likely, the increased concentrations measured during these two periods, compared to typical "Continental" concentrations, suggest that actual air masses that at least partially passed Seville have been probed here. Generally both "Marine" periods show very similar evolution of the measured time series, characterized by low concentrations over extended time intervals. During the early phase of the first period, increased concentrations of some aerosol parameters could be an indication of re-circulation of continentally influenced air masses. However, also ship emissions could be the cause of these elevated concentrations. Land-sea breeze has been identified to slightly twist locally measured wind directions when air is flowing along the coastline. However, its effect seems to be sufficiently 
Table 2. Averaged submicron mass concentrations and fractions of total $\mathrm{PM}_{1}$ for the common HR-ToF-AMS species and black carbon within the categorized air masses. For each category the total time of measurements is listed that are used for the evaluation. For each species, standard deviations are listed as an estimate for the inner-category variability.

\begin{tabular}{|c|c|c|c|c|c|c|c|}
\hline & & $\begin{array}{l}\text { Seville } \\
26 \mathrm{~h}\end{array}$ & $\begin{array}{c}\text { Continental } \\
60 \mathrm{~h}\end{array}$ & $\begin{array}{c}\mathrm{P}+\text { Huelva } \\
11 \mathrm{~h}\end{array}$ & $\begin{array}{c}\mathrm{M}+\text { Huelva } \\
75 \mathrm{~h}\end{array}$ & $\begin{array}{c}\mathrm{P}+\text { Marine } \\
59 \mathrm{~h}\end{array}$ & $\begin{array}{c}\text { Marine } \\
26 \mathrm{~h}\end{array}$ \\
\hline AMS-Org & $\begin{array}{c}\mu \mathrm{g} \mathrm{m}_{\%}^{-3} \\
\end{array}$ & $\begin{array}{c}3.2 \pm 2.2 \\
58\end{array}$ & $\begin{array}{c}2.5 \pm 1.7 \\
64\end{array}$ & $\begin{array}{c}4.2 \pm 1.5 \\
61\end{array}$ & $\begin{array}{c}1.8 \pm 1.3 \\
45\end{array}$ & $\begin{array}{c}0.78 \pm 0.63 \\
46\end{array}$ & $\begin{array}{c}0.46 \pm 0.42 \\
27\end{array}$ \\
\hline $\mathrm{AMS}-\mathrm{SO}_{4}$ & $\underset{\%}{\mu \mathrm{g} \mathrm{m}^{-3}}$ & $\begin{array}{c}0.88 \pm 0.29 \\
16\end{array}$ & $\begin{array}{c}0.49 \pm 0.27 \\
13\end{array}$ & $\begin{array}{c}0.62 \pm 0.33 \\
9.0\end{array}$ & $\begin{array}{c}1.1 \pm 0.81 \\
28\end{array}$ & $\begin{array}{c}0.50 \pm 0.44 \\
29\end{array}$ & $\begin{array}{c}0.91 \pm 0.43 \\
54\end{array}$ \\
\hline AMS-NH 4 & $\operatorname{\mu g~m}_{\%}^{-3}$ & $\begin{array}{c}0.35 \pm 0.12 \\
6.4\end{array}$ & $\begin{array}{c}0.22 \pm 0.11 \\
5.6\end{array}$ & $\begin{array}{c}0.45 \pm 0.38 \\
6.5\end{array}$ & $\begin{array}{c}0.43 \pm 0.33 \\
11\end{array}$ & $\begin{array}{c}0.17 \pm 0.15 \\
10\end{array}$ & $\begin{array}{c}0.15 \pm 0.089 \\
8.8\end{array}$ \\
\hline $\mathrm{AMS}-\mathrm{NO}_{3}$ & $\begin{array}{c}\mu \mathrm{g} \mathrm{m}^{-3} \\
\%\end{array}$ & $\begin{array}{c}0.46 \pm 0.22 \\
8.4\end{array}$ & $\begin{array}{c}0.29 \pm 0.18 \\
7.4\end{array}$ & $\begin{array}{c}0.88 \pm 0.50 \\
13\end{array}$ & $\begin{array}{c}0.38 \pm 0.36 \\
9.5\end{array}$ & $\begin{array}{c}0.094 \pm 0.078 \\
5.5\end{array}$ & $\begin{array}{c}0.080 \pm 0.054 \\
4.7\end{array}$ \\
\hline AMS-Chl & $\mu \mathrm{g} \mathrm{m}_{\%}^{-3}$ & $\begin{array}{c}0.020 \pm 0.020 \\
0.36\end{array}$ & $\begin{array}{c}0.016 \pm 0.047 \\
0.41\end{array}$ & $\begin{array}{c}0.25 \pm 0.55 \\
3.6\end{array}$ & $\begin{array}{c}0.062 \pm 0.060 \\
1.6\end{array}$ & $\begin{array}{c}0.023 \pm 0.027 \\
1.4\end{array}$ & $\begin{array}{c}0.022 \pm 0.024 \\
1.3\end{array}$ \\
\hline $\mathrm{BC}$ & $\begin{array}{c}\mu \mathrm{g} \mathrm{m}^{-3} \\
\%\end{array}$ & $\begin{array}{c}0.54 \pm 0.43 \\
9.8\end{array}$ & $\begin{array}{c}0.35 \pm 0.24 \\
9.0\end{array}$ & $\begin{array}{c}0.5 \pm 0.14 \\
7.2\end{array}$ & $\begin{array}{c}0.29 \pm 0.23 \\
7.3\end{array}$ & $\begin{array}{c}0.17 \pm 0.17 \\
10\end{array}$ & $\begin{array}{c}0.050 \pm 0.082 \\
2.9\end{array}$ \\
\hline $\begin{array}{l}\text { Total Conc } \\
\text { TEOM Con }\end{array}$ & $\begin{array}{l}\mu \mathrm{g} \mathrm{m}^{-3} \\
\mu \mathrm{g} \mathrm{m}^{-3}\end{array}$ & $\begin{array}{l}5.5 \pm 3.3 \\
4.4 \pm 2.8\end{array}$ & $\begin{array}{l}3.9 \pm 2.6 \\
3.3 \pm 2.5\end{array}$ & $\begin{array}{l}6.9 \pm 3.4 \\
6.4 \pm 3.6\end{array}$ & $\begin{array}{l}4.0 \pm 3.1 \\
4.2 \pm 2.8\end{array}$ & $\begin{array}{l}1.7 \pm 1.5 \\
2.1 \pm 1.4\end{array}$ & $\begin{array}{l}1.7 \pm 1.1 \\
2.2 \pm 1.4\end{array}$ \\
\hline
\end{tabular}

small to prevent significant mixing of marine and continentally influenced air masses in the identified source categories. As also shown in Fig. 4, the highest concentrations observed on 28 November 2011 were not considered in the study due to an air mass change occurring during this time. Trajectories for this time period show a complex path and a trend, moving further to the West from hour to hour. Therefore, they were not classified into one of the categories. A more indepth analysis of the influence of topography and transport height on trajectory calculations was performed by scientists of INTA (National Institute for Aerospace Technology) and will be published elsewhere.

\section{Results}

\subsection{Aerosol composition of selected air mass categories}

\subsection{1 $\mathbf{P M}_{1}$ concentrations}

The chemical composition of the submicron aerosol, divided into the most common AMS species (organics, sulfate, nitrate, ammonium, chloride) and black carbon (BC) is presented for each of the air masses in Table 2 and in the pie charts of Fig. 5. Here the total $\mathrm{PM}_{1}$ mass concentrations are defined as the sum of all AMS and BC mass concentrations. The lowest average $\mathrm{PM}_{1}$ mass concentration was found in air masses transported over the Atlantic Ocean $\left(1.7 \pm 1.1 \mu \mathrm{g} \mathrm{m}^{-3}\right.$ ) (see Table 2 ). This value was about two to four times lower than the values recorded in air masses of "Continental" $\left(3.9 \pm 2.6 \mu \mathrm{g} \mathrm{m}^{-3}\right)$ and urban ("Huelva"/"Seville", $4.0 \pm 3.1$ and $6.9 \pm 3.4 \mu \mathrm{g} \mathrm{m}^{-3}$ ) origins. Even though the difference in $\mathrm{PM}_{1}$ concentrations are
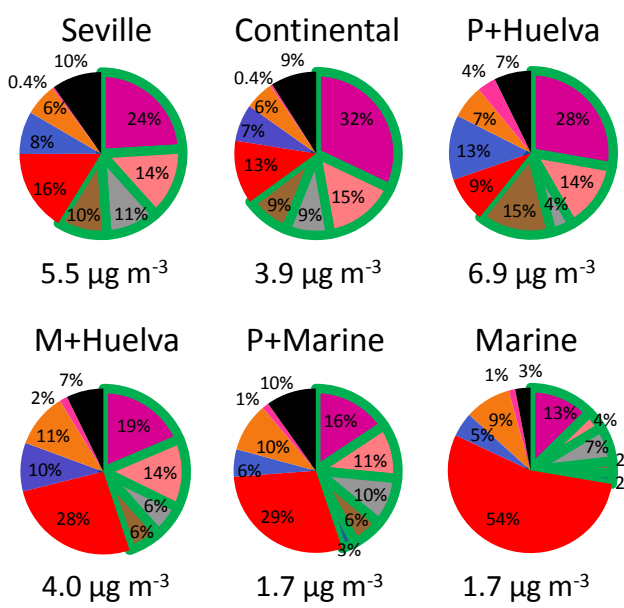

$1.7 \mu \mathrm{g} \mathrm{m} \mathrm{m}^{-3}$

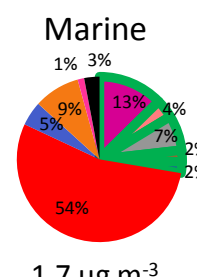

- Organic

- Sulfate

- Ammonium

- Nitrate

- Chloride

- $\mathrm{BC}$

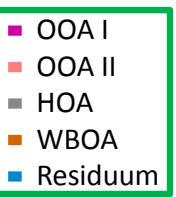

Fig. 5. Pie charts of the submicron aerosol composition of the $\mathrm{PM}_{1}$ for each air mass type consisting of organics (green), sulfate (red), ammonium (orange), nitrate (blue), chloride (purple) and black carbon (black). Organic material was further separated into OOA I (dark purple), OOA II (salmon), HOA (grey) and WBOA (brown) using PMF. The residuum (light blue) cannot be associated with any of these sources or components.

not significant within the one standard deviation boundaries, the trend is clearly evident. Despite the large variability within each category, the values for the air from the Atlantic Ocean largely differ from those of the other two categories. Regarding the whole campaign, total $\mathrm{PM}_{1}$ average mass concentrations were $4.0 \pm 2.5 \mathrm{\mu g} \mathrm{m}^{-3}$ while black carbon contributes $7.9 \%\left(0.32 \mu \mathrm{g} \mathrm{m}^{-3}\right)$ to this value. 


\subsubsection{Particulate organics}

Firstly, we note that the organics, sulfate and nitrate NR-PM (non-refractory particulate matter with $d_{\mathrm{p}} \leq 1 \mu \mathrm{m}$ ) aerosol concentrations show the most significant levels and also the most contrasting variations dependent on air mass origin. Therefore, they largely determine the chemical character of the aerosol. The highest organic matter fraction (64\%) was measured in the "Continental" air mass category. Biogenic precursor emissions in addition to emissions from frequent biomass burning activities originating from the surrounding pine and eucalyptus forests and the agricultural fields were transported downwind towards the coastal measurement site and generate secondary organic aerosol mass. In addition, anthropogenic sources also result in the generation of organic particulate matter. While the consistently high organic content is the dominant fraction in all air masses that passed the continent, in the "Marine" category sulfate plays the major role. To distinguish between different types of organics and to gain further insights into sources and processes affecting the organic composition results of a factor analysis study are presented in Sect. 3.4.

\subsubsection{Non-sea-salt particulate sulfate}

Generally, sulfate is a more regionally influenced component. While in "Continental" influenced air masses $13 \%$ $\left(0.49 \pm 0.27 \mu \mathrm{g} \mathrm{m}^{-3}\right)$ of $\mathrm{PM}_{1}$ consists of "sulfate", in the "Marine + Huelva" air mass category a fraction of $28 \%$ $\left(1.1 \pm 0.81 \mathrm{\mu g} \mathrm{m}^{-3}\right)$ was registered. In the marine boundary layer (MBL) sulfur compounds are quite common (Charlson et al., 1987; Zorn et al., 2008) as the ocean is a large source for atmospheric sulfur (Barnes et al., 2006). In addition, shipping emissions of marine transport in the Strait of Gibraltar play an important role as reported by Pey et al. (2008). Therefore, "sulfate" is the most abundant species of the "Marine" submicron non-refractory aerosol with a fraction of $54 \%\left(0.91 \pm 0.43 \mu \mathrm{g} \mathrm{m}^{-3}\right)$. The "sulfate" aerosol is further characterized (see Sect. 3.3) by analyzing the acidity since it affects aerosol hygroscopic growth, toxicity and heterogeneous reactions (Sun et al., 2010).

\subsubsection{Particulate nitrate}

As a result of a wide variety of industrial and traffic emission sources located in Huelva, nitrate formed by photochemical oxidation of nitrous oxides is the major inorganic fraction of the aerosol composition in the "Portugal + Huelva" $\left(13 \%, 0.88 \pm 0.50 \mu \mathrm{g} \mathrm{m}^{-3}\right)$ air mass category. While in "Marine + Huelva" $\left(9.5 \%, 0.38 \pm 0.36 \mu \mathrm{g} \mathrm{m}^{-3}\right)$ and "Seville" $\left(8.4 \%, 0.46 \pm 0.22 \mu \mathrm{g} \mathrm{m}^{-3}\right)$ air masses nitrate occurs as second most abundant inorganic fraction. It is well known that nitrate is a major content in fine particles from cities, urban and industrial regions (Takami et al., 2005). In addition, source apportionment studies conducted in the An- dalusian region showed higher average nitrate values in stations with a high traffic influence (de la Rosa et al., 2010). However, ammonium nitrate is volatile and reacts quickly during transport (Takami et al., 2005). The large variability of concentrations within the air mass categories is caused by the different kinds of emissions from short distances and changing wind directions.

\subsubsection{Particulate ammonium}

As a major fraction of total inorganic species, nitrate is followed by ammonium in all air mass types except both "Marine" categories where even less nitrate than ammonium was observed. Nevertheless, ammonium precursor sources in the marine boundary layer (Jickells et al., 2003) are not sufficiently abundant to neutralize the present sulfate. For the continentally influenced air masses instead, sources of ammonium include agricultural activities, manures, biomass burning or soils (Bouwman et al., 1997; Hock et al., 2008). The fertilizer production industries in Huelva (Perez-Lopez et al., 2010) provide an increased delivery of ammonia (Carretero et al., 2005) resulting in highest ammonium concentrations in "Portugal + Huelva" $\left(0.45 \pm 0.38 \mu \mathrm{g} \mathrm{m}^{-3}\right)$ and "Marine + Huelva" $\left(0.43 \pm 0.33 \mu \mathrm{g} \mathrm{m}^{-3}\right)$ air masses.

\subsubsection{Particulate chloride}

The measured chloride content is in the order of 0.4 to $3.6 \%$ within all air masses. However, average chloride values are not dominant in the "Marine" air mass categories as the ToF-AMS cannot measure sea salt (sodium chloride) with significant efficiency (Zorn et al., 2008). In contrast, both "Portugal + Huelva" $\left(3.6 \% ; 0.25 \pm 0.55 \mathrm{\mu g} \mathrm{m}^{-3}\right)$ and "Marine + Huelva" $\left(1.6 \%, 0.062 \pm 0.060 \mu \mathrm{g} \mathrm{m}^{-3}\right)$ air masses are influenced by industrial emissions (e.g. organic chloride species) likely responsible for up to nine times enhanced $\mathrm{PM}_{1}$ chloride concentrations compared to "Continental" $\left(0.41 \% ; 0.016 \pm 0.047 \mu \mathrm{g} \mathrm{m}^{-3}\right)$ air mass types. Lowest chloride values were registered in the "Seville" category $\left(0.36 \%, 0.020 \pm 0.020 \mu \mathrm{g} \mathrm{m}^{-3}\right)$. Since the measured chloride concentrations are either below the detection limit $\left(0.02 \mu \mathrm{g} \mathrm{m}^{-3}\right)$ or the resulting mass concentrations show large variability, we cannot identify clear differences within the individual source categories for this species.

\subsubsection{Black carbon}

The influence of air mass histories is also evident in average black carbon (BC) mass concentrations. Enhanced average $\mathrm{BC}$ fractions were measured in polluted Huelva (7\%) and "Continental" (9\%) air masses (see Table 2) while lowest BC mass fractions occur in the "Marine" $(3 \%)$ influenced air mass category, being typically below the detection limit $\left(0.1 \mu \mathrm{g} \mathrm{m}^{-3}\right)$. Therefore, an air mass history change leads to a change in measured BC mass concentrations at the site as well. 


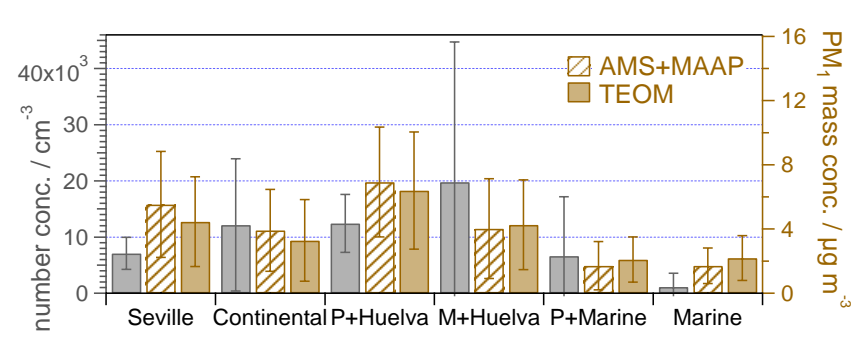

Fig. 6. Averaged particle number (grey) and mass (brown) concentrations for the individual air mass categories. While hatched brown bars represent averaged submicron $\mathrm{PM}_{1}$ mass concentrations determined by adding HR-ToF-AMS species and black carbon concentrations, brown filled bars show $\mathrm{PM}_{1}$ mass concentrations measured using the TEOM. Standard deviations show the variability for the mentioned parameters within each air mass category.

\subsubsection{Aerosol mass concentrations}

Figure 6 illustrates the dependence of average mass concentrations measured with the TEOM (filled brown) and AMS+MAAP (hatched brown) in $\mathrm{PM}_{1}$ as well as averaged aerosol number concentrations (CPC, grey) on air mass types. Although both mass concentrations are characterized by large variability (in terms of standard deviations), it is obvious that for all marine influenced source regions TEOM slightly exceeds AMS+MAAP mass concentrations. This is likely due to sea spray which is the major source of particulate matter within the marine boundary layer, consisting of sodium chloride aerosol particles (Warneck, 1988), which cannot be measured efficiently with the AMS. For the "Seville", "Continental" and "Portugal + Huelva" air mass categories AMS+MAAP concentrations are larger than TEOM mass concentrations. This could be due to volatile substances that are potentially not completely registered using the TEOM.

\subsubsection{Particle number concentrations}

The number concentration levels within the "Continental", "Marine + Huelva", "Portugal + Marine" and "Marine" air mass categories show significant variability, reflected in large standard deviations. For the first two of these source sectors the large variability is caused by the frequent occurrence of particle nucleation events. For the "Portugal + Marine" category particle nucleation is also possible, however, we can neither clearly identify nor exclude such events unambiguously. Another potential cause is the inhomogeneous mixture of polluted continental air with clean marine air, and for the "Marine" category the generally low values are associated with significant variability, potentially caused by individual ship emission plumes. Despite the strong variations in number concentrations, a general trend is clearly visible and major differences occur between the group of "Continental", "Marine + Huelva" and "Portugal + Marine" air masses compared to the group of "Seville", "Portugal + Huelva" and "Marine" air masses: the ratios of particle number to particle mass concentration bar heights in Fig. 6 differ significantly between these two groups of air masses. While the brown colored bars corresponding to $\mathrm{PM}_{1}$ mass concentrations referred to the grey ones representing number concentrations are approximately four times as high for the "Marine" category and 2 times as high for "Seville", almost the same bar heights were obtained for the "Continental" and "Portugal + Marine" air mass categories. The presence of freshly produced aerosol originating from nearby particle sources in "Marine + Huelva" air mass types affect both physical aerosol concentrations in a way that large particle number concentrations associated with lower aerosol mass concentrations were measured, compared to the other air mass types. On the other hand, the aging of the aerosol during regional transport of urban emissions, like it is the case for "Seville" or aged "Marine" aerosol, is expressed in lower number but enhanced particle mass concentrations. Due to the fact that "Marine + Huelva" air mass trajectories extend over the whole area of Huelva city compared to "Portugal + Huelva", crossing mainly the north of the city, related concentrations behave differently. Typically, the relation of the particle mass and number concentration shows low correlation (Buonanno et al., 2010). Similar information is provided by the following particle size distributions with additional details.

\subsection{Variability of particle size distributions}

Figure 7 shows the size distributions of averaged number, surface and volume concentrations measured for the different air mass categories using the FMPS (a) and the OPC (b). The FMPS covers the particle size range $7-523 \mathrm{~nm}$ (a), whereas the OPC particle size range is from $320 \mathrm{~nm}$ until $32 \mu \mathrm{m}$ (b). The FMPS registers the mobility diameter of the aerosol particles while the OPC measures the optical particle diameter. Since the optical properties of the measured particles are not known well enough, no attempt was made to convert these different particle diameters into a common type of particle diameter. Therefore, both size distributions are shown in separate panels and each mode will be discussed separately.

Aging of aerosol particles is often associated with coagulation of small particles with each other or onto larger preexisting particles, and with condensational growth of vapors onto available particle surfaces; resulting in an increase of particle size with time, in a decrease of number concentrations and in a change of the particle composition as well. Under the condition that particles are larger than $40 \mathrm{~nm}$ several hours after particle formation started, e.g. during the growth phase of a nucleation event, changes in particle composition can be investigated using the AMS. However, this topic will be the focus of a future publication.

Within the measured FMPS mobility diameter size range, modes in the averaged number distributions were found in the nuclei mode nearly without exception within all 


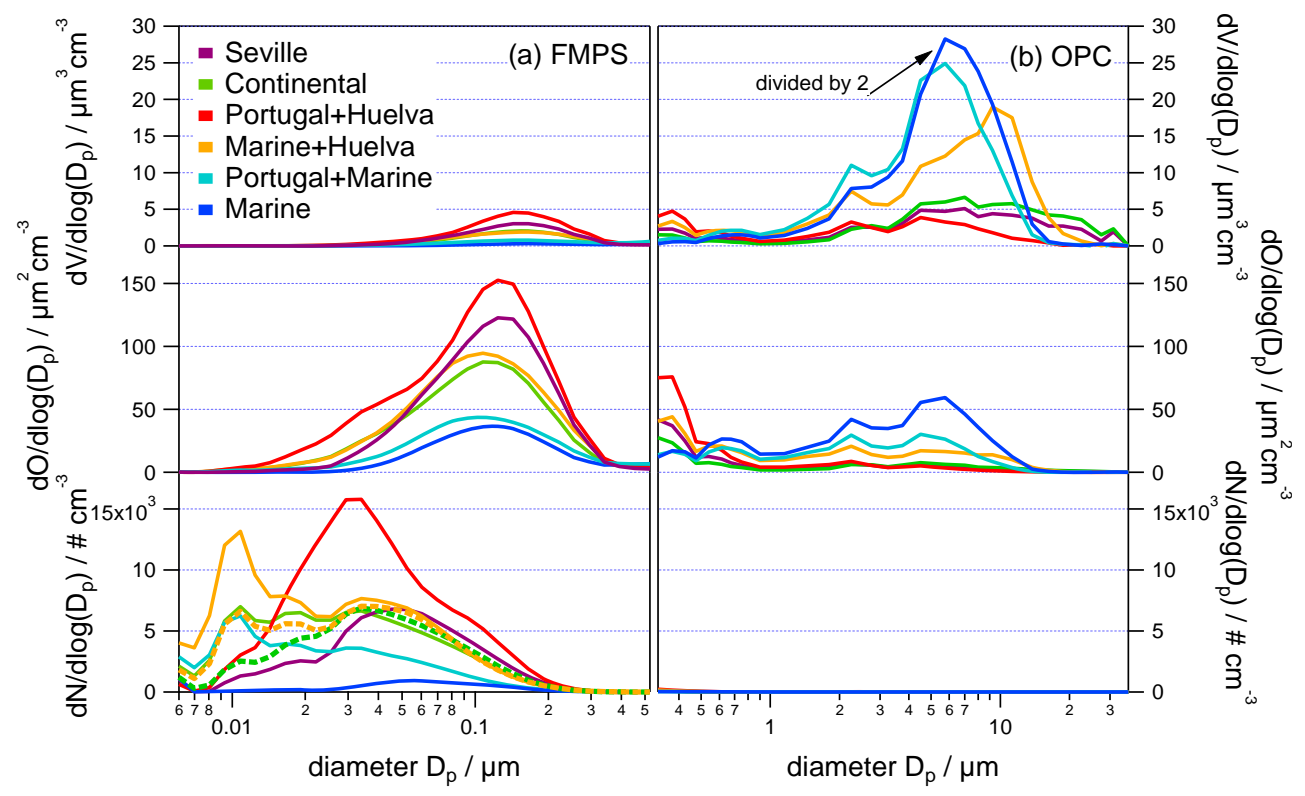

Fig. 7. Averaged particle size distributions in the size range of $7 \mathrm{~nm}$ until $32 \mu \mathrm{m}$ for all air mass types using the FMPS (a) and OPC (b) data. The FMPS registers particle diameters in a size range of $7-523 \mathrm{~nm}\left(D_{\text {mob }}\right)$ while the OPC covers the particle size range $320 \mathrm{~nm}$ until $32 \mu \mathrm{m}\left(D_{\text {opt }}\right)$. Dotted lines in the number distribution show averaged concentrations without considering new particle formation events for the "Marine + Huelva" and the "Continental" categories. The observed discrepancies could be due to the fact that both instruments base on different measurement methods and both reach their limits regarding the smallest and largest channels.

continental and Huelva influenced air mass categories. FMPS number size distributions are clearly influenced by frequently occurring particle formation events within these air mass categories. This impact is shown in Fig. 7a using solid and dotted lines of the same color for data where all measurements are considered or where nucleation periods are excluded for the "Continental" and "Marine + Huelva" air mass categories. For the "Portugal + Marine" category we also measured a mode around $10 \mathrm{~nm}$ but we can neither identify nor exclude unambiguously new particle formation events for this source category. The significant urban pollution in Huelva causes the highest particle number concentrations for "Portugal + Huelva" including particles in a wide size range with a mode diameter around $30 \mathrm{~nm}$. In Huelvarelated air masses, new particles are also formed by nucleation. In addition, industrial exhaust gases condense onto pre-existing particles. Nevertheless, as new particle formation will be dealt within a future paper, we will not go further into details here. For the "Marine" air mass category, the monomodal number size distribution with low total number concentrations indicates processed aerosol.

The surface area size distributions (Fig. 7) with accumulation mode diameters around $150 \mathrm{~nm}$ have a similar monomodal shape for each category except for the "Portugal + Huelva" air masses which are five times as high as those from "Marine" air mass types. The extreme urban pollution in Huelva with maximum number concentrations in the $30 \mathrm{~nm}$ size range result in maximum surface area concentra- tions and in a fronting of the particle surface area distribution as well.

The volume size distributions measured primarily using the OPC (Fig. 7b) show interesting features in the coarse mode up to $2 \mu \mathrm{m}$ optical particle diameter. Volume concentrations of all marine influenced air masses are higher than those originating from "Continental" or urban source regions. While the averaged volume size distributions for "Marine" and "Portugal + Marine" air masses both have their maxima at $5.7 \mu \mathrm{m}$ and also a similar shape, the "Marine + Huelva" size distribution is clearly shifted towards larger diameters and therefore has its dominant mode around $10 \mu \mathrm{m}$. The major particle source in marine enviroments is sea spray therefore sodium chloride particles contribute significantly to the volume size distributions in "Marine" and "Portugal + Marine" air masses. The "Marine + Huelva" size distribution is affected by both, sea salt particles and particles originating from Huelva's industries. "Continental" and "Seville" categories have nearly the same volume concentrations and shape, but compared to all marine influenced air masses they are shifted towards larger optical particle sizes.

\subsection{Variation of the acidity of the submicron aerosol}

The aerosol variability between different air mass types was further characterized by analyzing the contributors that influence the aerosols' acidity, since it has an important impact on both, aerosol hygroscopic growth, toxicity as well as 

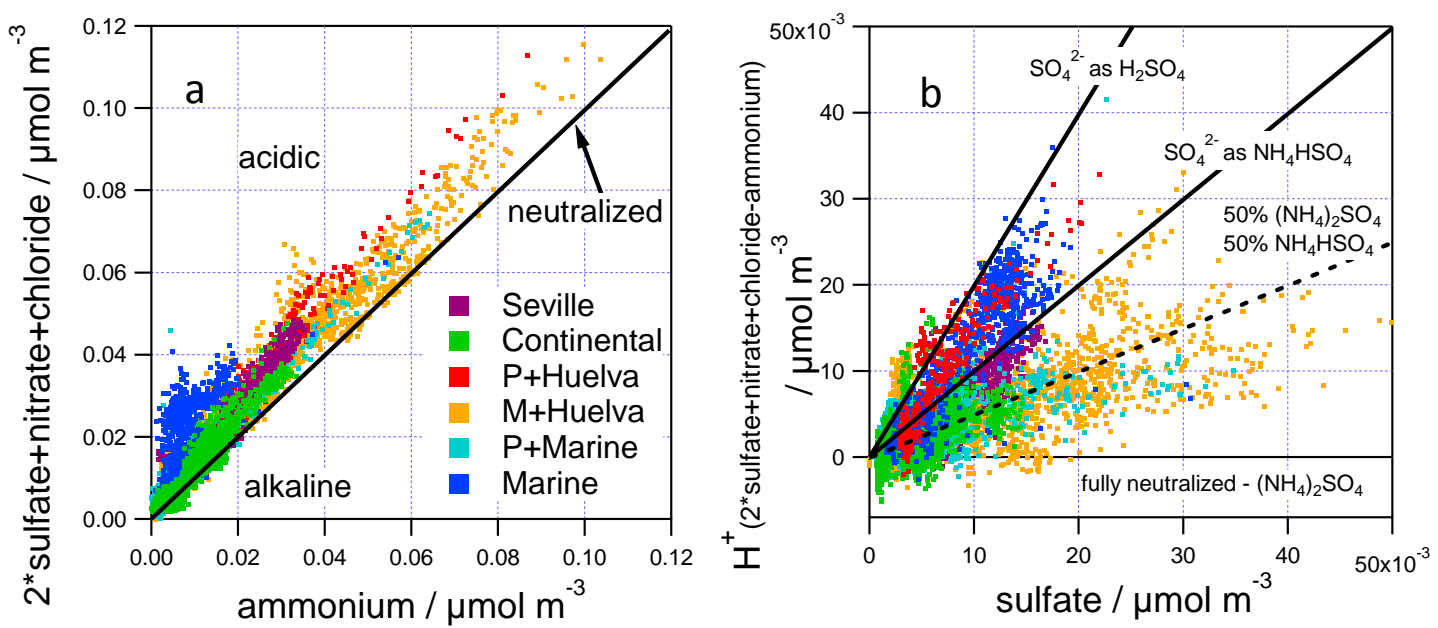

Fig. 8. Correlations illustrating the difference of the ion balance (a) dependent on the air mass origin. The scatter plot (b) serves for the identification of the sulfur species ammonium sulfate $\left(\left(\mathrm{NH}_{4}\right)_{2} \mathrm{SO}_{4}\right)$, ammonium bisulfate $\left(\mathrm{NH}_{4} \mathrm{HSO}_{4}\right)$ and sulfuric acid $\left(\mathrm{H}_{2} \mathrm{SO}_{4}\right)$ within the different aerosols. Points represent 2 min average values.

heterogeneous reactions (Sun et al., 2010). In this context we examined the relative abundance of the inorganic ToF-AMS species sulfate, ammonium and nitrate in the submicron $\mathrm{PM}_{1}$ aerosol, particularly with regard to the differences in the ion balance in dependence of the air mass types.

A scatter plot of the sum of molar sulfate, nitrate and chloride versus molar ammonium is shown in Fig. 8a to illustrate the degree of neutralization for the individual air mass classes. Sulfate was multiplied by a factor of 2 to reflect the molar ratio of sulfate versus ammonium in ammonium sulfate. The black line (1:1) indicates fully neutralized aerosol. Data points below this line are associated with alkaline aerosol, as ammonium concentrations are higher than needed to neutralize the anions while points lying above this line are associated with acidic aerosol. For most of the points, primarily in "Seville", "Continental", "Marine + Huelva" and "Portugal + Marine" air masses, the correlation of measured ammonium versus inorganic anions indicates that a major fraction of $\mathrm{PM}_{1}$ submicron aerosol was slightly acidic for most of the time while also neutralized aerosols occur. In "Portugal + Huelva" air masses, the sum of all inorganic AMS anionic compounds (sulfate, nitrate, chloride) exceeds ammonium which implies an acidic aerosol. As mentioned before, acidic sulfate originating from "Marine" air masses measured at this coastal site is due to negligible contribution of ammonium in this region. As shown in the studies of Jickells et al. (2003), ammonium sources are not very abundant in the MBL therefore particulate ammonium concentrations are much smaller than the concentration necessary for the neutralization of sulfate and nitrate (Coe et al., 2006; Allan et al., 2004, 2008). Although sodium chloride is the most abundant species in the marine boundary layer, the AMS only measures the NR-PM 1 aerosol fraction and therefore does not measure sodium chloride with significant effi- ciency (Zorn et al., 2008). For this reason we assume measured chloride is mostly present as ammonium chloride if it is neutralized, hence, it is included in the calculations of the ion balance. Regarding all air mass categories the averaged equivalent ratio is larger than one (see Fig. 8a), indicating that the aerosol at the measurement site was generally rather acidic.

Another focus was put on speciation of sulfur compounds expected to be found in the aerosol from the different source regions. While previous studies in Pittsburgh identified a sulfur mixture of ammonium sulfate $\left(\left(\mathrm{NH}_{4}\right)_{2} \mathrm{SO}_{4}\right)$, ammonium bisulfate $\left(\mathrm{NH}_{4} \mathrm{HSO}_{4}\right)$ and also small amounts of sulfuric acid $\left(\mathrm{H}_{2} \mathrm{SO}_{4}\right)$ (Zhang et al., 2007), Zorn et al. (2008) included the identification and quantification of methanesulfonic acid (MSA) in the analysis, which can be found ubiquitously in marine environments. Figure $8 \mathrm{~b}$ shows a scatter plot of acidrelated hydrogen $\left(\mathrm{H}^{+}\right)$present in the particle phase versus the molar sulfate concentration in the submicron particles. The $\mathrm{H}^{+}$molar concentration was estimated by subtracting the ammonium $\left(\mathrm{NH}_{4}^{+}\right)$molar concentration from the molar concentrations of the anions sulfate $\left(\mathrm{SO}_{4}^{2-}\right)$, nitrate $\left(\mathrm{NO}_{3}^{-}\right)$ and chloride $\left(\mathrm{Cl}^{-}\right)$(Zhang et al., 2007):

$\left[\mathrm{H}^{+}\right]=2 \cdot\left[\mathrm{SO}_{4}^{2-}\right]+\left[\mathrm{NO}_{3}^{-}\right]+\left[\mathrm{Cl}^{-}\right]-\left[\mathrm{NH}_{4}^{+}\right]$.

The black lines in Fig. 8b indicate the molar ratios that would correspond to $\left(\mathrm{NH}_{4}\right)_{2} \mathrm{SO}_{4}, \mathrm{NH}_{4} \mathrm{HSO}_{4}$ and $\mathrm{H}_{2} \mathrm{SO}_{4}$, the dashed line agrees with $50 \%\left(\mathrm{NH}_{4}\right)_{2} \mathrm{SO}_{4}$ and $50 \%$ $\mathrm{NH}_{4} \mathrm{HSO}_{4}$. To quantify the various "sulfate" aerosol components for the different air mass types in Table 3 the percentage of ammonium sulfate $\left(\left(\mathrm{NH}_{4}\right)_{2} \mathrm{SO}_{4}\right)$, ammonium bisulfate $\left(\mathrm{NH}_{4} \mathrm{HSO}_{4}\right)$, sulfuric acid $\left(\mathrm{H}_{2} \mathrm{SO}_{4}\right)$ and methanesulfonic acid (MSA) were calculated as follows: 
Table 3. Percentage contribution of ammonium sulfate $\left(\left(\mathrm{NH}_{4}\right)_{2} \mathrm{SO}_{4}\right)$, ammonium bisulfate $\left(\mathrm{NH}_{4} \mathrm{HSO}_{4}\right)$, sulfuric acid $\left(\mathrm{H}_{2} \mathrm{SO}_{4}\right)$ and methanesulfonic acid (MSA) to the species class "sulfate" for the selected air mass categories.

\begin{tabular}{lcccc}
\hline & $\begin{array}{c}\text { ammonium } \\
\text { sulfate } \\
\left(\left(\mathrm{NH}_{4}\right)_{2} \mathrm{SO}_{4}\right)\end{array}$ & $\begin{array}{c}\text { ammonium } \\
\text { bisulfate } \\
\left(\mathrm{NH}_{4} \mathrm{HSO}_{4}\right)\end{array}$ & $\begin{array}{c}\text { sulfuric } \\
\text { acid } \\
\left(\mathrm{H}_{2} \mathrm{SO}_{4}\right)\end{array}$ & $\begin{array}{c}\text { methanesulfonic } \\
\text { acid } \\
(\mathrm{MSA})\end{array}$ \\
\hline Seville & 28 & 72 & 0 & below LOD \\
Continental & 50 & 50 & 0 & below LOD \\
Portugal + Huelva & 0 & 72 & 28 & below LOD \\
Marine + Huelva & 32 & 68 & 0 & below LOD \\
Portugal + Marine & 26 & 74 & 0 & below LOD \\
Marine & 0 & 74 & 26 & 1 \\
\hline
\end{tabular}

$\mathrm{NH}_{4}^{+} \operatorname{excess}(\mathrm{mol})=\mathrm{NH}_{4}^{+}(\mathrm{mol})-\mathrm{NO}_{3}^{-}(\mathrm{mol})-\mathrm{Cl}^{-}(\mathrm{mol})$

$\mathrm{SO}_{4}^{2-} \operatorname{excess}(\mathrm{mol})=\mathrm{SO}_{4}^{2-}(\mathrm{mol})-\mathrm{NH}_{4}^{+} \operatorname{excess}(\mathrm{mol}) / 2$

$\% \mathrm{H}_{2} \mathrm{SO}_{4}=\mathrm{SO}_{4}^{2-} \operatorname{excess}(\mathrm{mol}) / \mathrm{SO}_{4}^{2-} \operatorname{total}(\mathrm{mol}) \cdot 100$

$\% \mathrm{MSA}=\mathrm{MSA}(\mathrm{mol}) / \mathrm{SO}_{4}^{2-} \operatorname{total}(\mathrm{mol}) \cdot 100$

$\%\left(\mathrm{NH}_{4}\right)_{2} \mathrm{SO}_{4}=100-\% \mathrm{H}_{2} \mathrm{SO}_{4}-\% \mathrm{MSA}$.

The fraction of $\mathrm{NH}_{4} \mathrm{HSO}_{4}$ for each category can be calculated stoichiometrically based on the molar ratios of $\left(\mathrm{NH}_{4}\right)_{2} \mathrm{SO}_{4}$ and $\mathrm{H}_{2} \mathrm{SO}_{4}$.

The "sulfate" classes $\left(\mathrm{NH}_{4}\right)_{2} \mathrm{SO}_{4}, \mathrm{NH}_{4} \mathrm{HSO}_{4}$ and $\mathrm{H}_{2} \mathrm{SO}_{4}$ were distinguished on the basis of the presence of the potential counter ions as we cannot separate the different sulfate species directly in our measurements. Therefore, we assume that ammonium first reacts with nitrate and chloride in the particles and chemical equilibrium exists. Likewise, excess ammonium reacts with sulfate to form ammonium sulfate in an equilibrium reaction. Finally, sulfate that could not be neutralized by ammonium has to be present as ammonium bisulfate or sulfuric acid. In Table 3 the relative contributions of the species $\left(\mathrm{NH}_{4}\right)_{2} \mathrm{SO}_{4}, \mathrm{NH}_{4} \mathrm{HSO}_{4}$ and $\mathrm{H}_{2} \mathrm{SO}_{4}$ to total "sulfate" are presented. For calculating MSA concentrations the Peak Integration by Key Analysis software (PIKA, http: //cires.colorado.edu/jimenez-group/ToFAMSResources, DeCarlo et al., 2006) was used to deconvolve the $m / z 79$ signal into three peaks: Bromine, a MSA fraction, and an organic fragment $\left(\mathrm{C}_{6} \mathrm{H}_{7}^{+}\right)$as described in Zorn et al. (2008). As shown in Table 3, the analysis indicates that MSA accounts for only a minor degree (1\%) of the total "sulfate" component class when "Marine" air masses arrive at the measurement site, while MSA concentrations in the other categories are below the detection limit $\left(6 \mathrm{ng} \mathrm{m}^{-3}\right)$.

Unlike in the studies of Zorn et al. (2008) a major fraction of the "sulfate" class in the "Marine" air mass category is contributed by ammonium bisulfate $(74 \%)$ while sulfuric acid $(26 \%)$ is the second major contributor (Fig. 8b). While sulfuric acid is produced from dimethyl sulfide (DMS) originating from phytoplankton or anaerobe bacteria (Charlson et al., 1987) and from sulfur dioxide $\left(\mathrm{SO}_{2}\right)$ from shipping emissions (Zorn et al., 2008), ammonium bisulfate is the result of the neutralization reaction between sulfuric acid and ammonia. In comparison, "Portugal + Huelva" air masses are influenced by nitrate precursor emission sources in Southern Huelva, causing the binding of a significant fraction of the available ammonium. This results in an ammonium bisulfate $(72 \%)$ to sulfuric acid $(28 \%)$ ratio that is even more acidic than those within the "Marine" air mass category (Table 3). On the contrary, ammonia is mostly present in the terrestrial boundary layer hence sulfurous aerosols are mostly composed of ammonium bisulfate and ammonium sulfate in the "Seville", "Marine + Huelva" and "Portugal + Marine" air mass types. For the "Continental" air mass category the ammonium sulfate to ammonium bisulfate ratio is balanced. This can also be seen in Fig. 8b based on the corresponding data points reflecting the $50 \%\left(\mathrm{NH}_{4}\right)_{2} \mathrm{SO}_{4} / 50 \% \mathrm{NH}_{4} \mathrm{HSO}_{4}$ line. Similar results were found during the OOMPH campaign: Zorn et al. (2008) found only a minor fraction (20$50 \%$ ) of neutralized aerosol during pristine marine dominated periods while continentally influenced air masses are often neutralized.

\subsection{Factor analysis of the organic aerosol using Positive Matrix Factorization (PMF)}

Another major objective of this study is to identify the main components and sources of the submicron organic aerosol. For this purpose positive matrix factorization (PMF) (Paatero, 1997; Paatero and Tapper, 1994) was used to analyze the AMS organics information using the evaluation tool developed by Ulbrich et al. (2009). Results of this analysis for the whole campaign period show four "factors", representing different aerosol types that explain an average of $97 \%$ of the total organic mass and can be associated with aerosol sources and components. Oxygenated organic aerosol (OOA I) was the major component that contributes on average $43 \%$ of the particulate organic mass during the whole measurement period. While OOA I, a highlyoxygenated OA, mostly represents secondary organic aerosol (SOA); OOA II, accounting for additional $23 \%$ of the organic mass, represents a less-oxygenated/processed, semivolatile OA (Ulbrich et al., 2009). A hydrocarbon-like organic aerosol type (HOA, 16\%) as well as aerosol from 

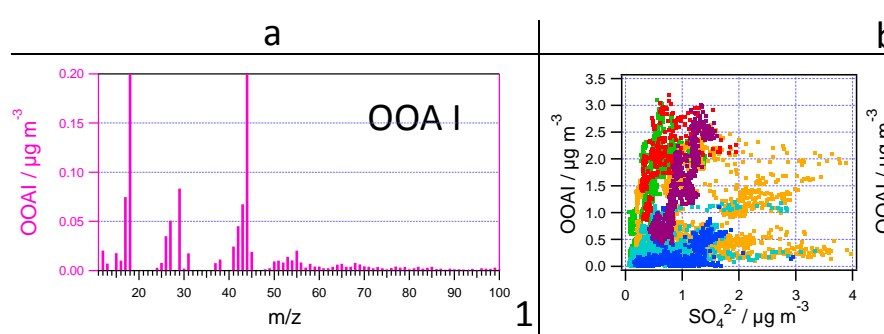

\begin{tabular}{l|l}
$\mathrm{b}$ & $\mathrm{c}$
\end{tabular}
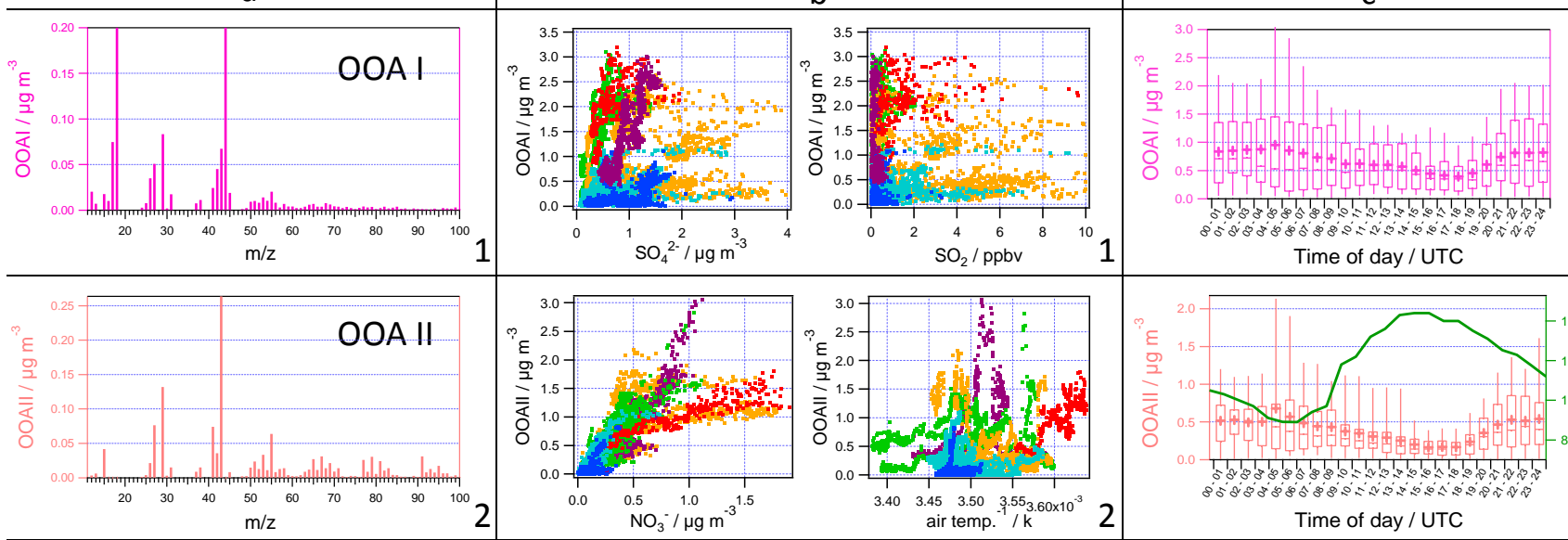

Time of day / UTC
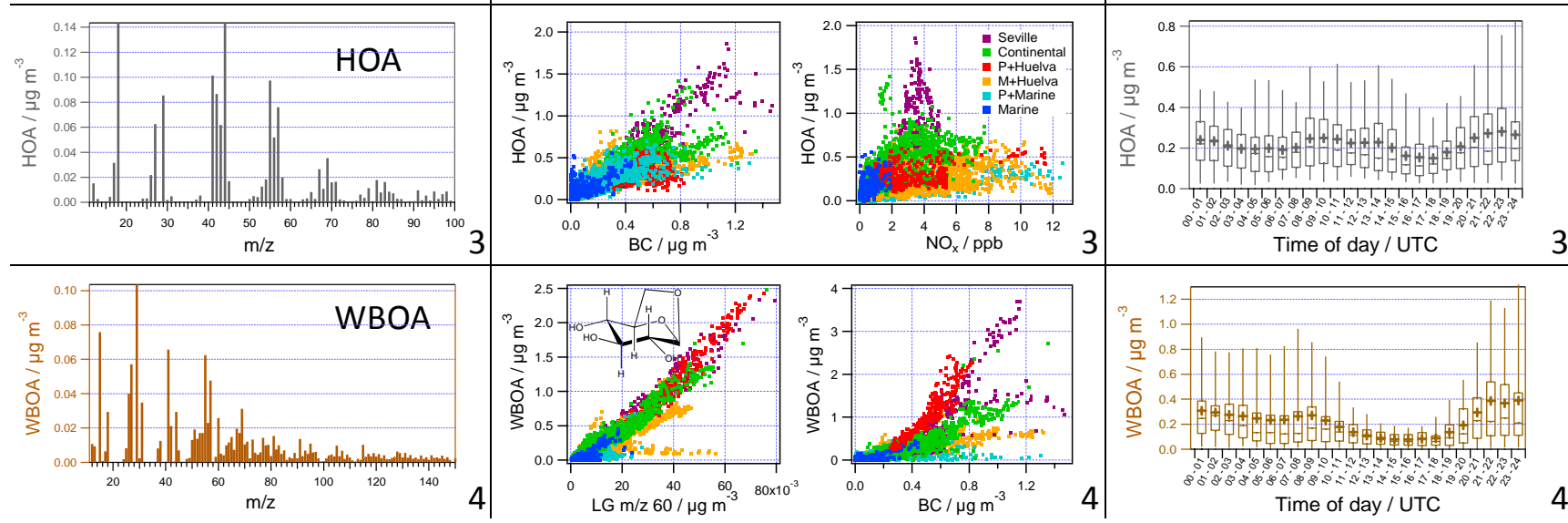

Fig. 9. Mass spectra (a), correlations (b) and diurnal variation box plots (c) of OOA I (dark purple, 1), OOA II (salmon, 2), HOA (grey, 3) and WBOA (brown, 4) organic aerosol types. Mass spectral markers were compared to reference spectra (not shown). The four factors were correlated with aerosol species (sulfate, nitrate, $\mathrm{m} / \mathrm{z}, 60$ as levoglucosan tracer, black carbon), trace gases (nitrogen oxide, sulfur dioxide) and meteorological parameters (air temperature) (b). Box plots of the diurnal variation for the whole campaign (c) show the median, mean and the $25 / 75 \%$ percentiles. The whiskers indicate the $5 / 95 \%$ interquartile span. Points in the correlations (b) represent 2 min average values.

wood burning emissions (WBOA, $15 \%$ ) were identified in this study by comparing the mass spectra of the PMF factors to measured ambient reference spectra (http://cires.colorado. edu/jimenez-group/AMSsd/).

\subsubsection{Comparison of mass spectra with reference spectra}

In Fig. 9a calculated average mass spectra of all four PMF factors (OOA I, OOA II, HOA, WBOA) are shown. Significant mass fragments for highly-aged OOA I (Fig. 9a/1) are $m / z 18,27,41,43,44,55,69$ while marker peaks at $m / z 27,29,41,43,55,67,79$ are characteristic for OOA II (Fig. 9a/2). Both factors correlate well with reference spectra shown in Lanz et al. (2007) $\left(R^{2}=0.96\right.$ for OOA I; $R^{2}=0.90$ for OOA II). Unlike in the studies of Lanz et al. (2007), Zhang et al. (2005) and Ulbrich et al. (2009), the HOA mass spectrum found in this work (Fig. 9a/3) is dominated by $\mathrm{m} / \mathrm{z} 44$ and therefore $\mathrm{m} / \mathrm{z} 18$ and 17 mass frag- ments are enhanced as well, because their calculation was bound to $m / z, 44$ in the analysis. Apart from this, the typical characteristic peaks for hydrocarbons $(\mathrm{m} / \mathrm{z} 41,43,55$, $57,69,81,95)$ exist. Therefore, we assume this factor represents a "slightly oxidized HOA". For this reason, the HOA reference spectrum (Zhang et al., 2005) does not correlate very well $\left(R^{2}=0.58\right)$ with our HOA spectrum. Moreover, regarding the high resolution mass spectra at $m / z$ 44, the $\mathrm{C}_{3} \mathrm{H}_{8}^{+}$peak $\left(m / z\right.$ 44.06) overlaps the $\mathrm{CO}_{2}^{+}$peak $(m / z$ 43.99) and could not be separated with the AMS as the mass resolution was too low. Therefore, this could also be a reason for the enhanced $m / z 44$ signal which is not associated with oxidized organic aerosol. In addition a spectral pattern was determined in the fourth factor in this study which is similar to the wood burning reference spectrum in Lanz et al. (2007) $\left(R^{2}=0.83\right)$, containing prominent peaks at $m / z 15,29,41$, 55, 60, 69, 73, 91 (WBOA, Fig. 9a/4). 


\subsubsection{Quality assurance for the mathematically calculated PMF results}

To validate the PMF results a variety of tests have been performed with the data set. One of these validation exercises concerned the weighting of particular $m / z$. For these tests PMF has been performed using different sets of input parameters (weighting of particular $m / z$ in the input mass spectra) and the related results have been compared to each other. According to these calculations the individual $\mathrm{m} / \mathrm{z}$ in the average mass spectra of the four factors (OOA I, OOA II, HOA, WBOA) have an uncertainty in the order of $5 \%$; also the calculated mass concentrations associated with the four factors have an uncertainty of approximately $5 \%$ if lowest aerosol mass concentrations were not considered. PMF computations consider so-called "fpeak" values that allow examining "rotations" and "seeds" to explore additional solutions by starting the algorithm from several pseudorandoms (U1brich et al., 2009). Both variables have to be set by the user in the data analysis process. Since no clear rules exist which values have to be used for "fpeak" and "seeds", this results in an additional uncertainty of the peak intensities of the mass spectra of 17-34\% dependent on the factor if "fpeaks" were varied, while the uncertainty varies between $2-19 \%$ with a change of the "seeds". The uncertainty of averaged mass concentrations of the time series varies between 13-36\% for the different factors when "fpeak" is varied. For a variation of the "seeds" this uncertainty is in the order of $1-10 \%$. Generally the HOA and WBOA factors have a larger uncertainty than OOA I and OOA II. After several tests were conducted with PMF, we decided to take the four factor solution using "fpeak" and "seed" values of zero. However, it has to be noted that these factors are subjectively selected and result in the uncertainties in both the mass spectra and average mass concentrations described above. Additionally, the instrument uncertainty of the AMS (25-30\%) has also to be taken into account.

By adding an additional fifth factor in the PMF analysis a meaningless factor appears as a consequence of "splitting" one of the previous factors like also described in the studies of Sun et al. (2010). Therefore, this factor did not improve the PMF results. To assure the best possible PMF solution the factors were further tested, not only on the basis of the mass spectral (MS) signature but also correlations of the OOA I, OOA II, HOA and WBOA mass concentration time series (see Fig. 9b), with those of other measured aerosol species, trace gases and meteorological parameters were accomplished.

\subsubsection{Diurnal cycles and correlations of particulate organics with aerosol and gas phase species}

In Fig. 9b/1 the sulfate mass concentrations are correlated with those of the PMF OOA I factor. Unlike in the studies of Lanz et al. (2007), Zhang et al. (2005) and Ulbrich et al. (2009) OOA I is only weakly correlated with particulate sulfate. This might be due to the variety of types of emission sources around the measurement site. On the one hand the strongly industrialized Huelva estuary or the marine category, where sulfate plays an important role (54\% of total aerosol, Table 2), and on the other hand source categories with lower sulfate abundance cause extreme changes of sulfate concentrations as discussed in Sect. 3.3 with changing meteorological conditions (wind directions). For this reason, also the sulfur dioxide concentrations vary between $0.3 \mathrm{ppb}$ in the "Marine" and 2 ppb in the "Marine + Huelva" air mass category and correlate reasonably with sulfate concentrations $\left(R^{2}=0.4\right)$ but not with OOA I. These variations in sulfur dioxide and sulfate concentrations do not necessarily have to be associated with changes in OOA I concentrations since OOA I has its sources in a different set of air mass categories compared to sulfate.

According to the diurnal cycle (Fig. 9c/1), OOA I only show a weak photochemical dependence as expected, since it reflects aged highly-oxidized OA. Contrary, the temporal behavior of OOA II, a less aged semi-volatile organic aerosol component, shows typical maximum concentrations at night. This could be explained by the strong anti-correlation of the diurnal OOA II cycle with the temperature cycle (Fig. 9c/2) which could be the reason for an accumulation of oxidized organic products in the vapor phase during the day that condense onto the particles surfaces preferentially during the night (Lanz et al., 2007). AMS-nitrate is also a temperaturesensitive species correlating reasonably well with OOA II $\left(R^{2}=0.5\right.$, Fig. 9b/2).

As observed in many previous studies (Lanz et al., 2007; Zhang et al., 2005), prominent features of the HOA diurnal patterns around 08:00-13:00 UTC and 20:00 UTC (Fig. 9c/3) result from morning and evening rush-hours and other human activities. The HOA time series is correlated with the primary emission tracer black carbon $\left(R^{2}=0.6\right)$ but not with $\mathrm{NO}_{\mathrm{x}}\left(R^{2}=0.2\right) . \mathrm{NO}_{\mathrm{x}}$ is formed by oxidation of nitrogen in combustion engines at high temperatures and is also emitted by industrial sources and biomass burning. Hence, as mentioned by Lanz et al. (2007), $\mathrm{NO}_{\mathrm{x}}$ is not only a marker for traffic emissions and HOA should not be regarded as pure vehicle exhaust marker, likely resulting in the relatively poor correlation observed between these species.

The WBOA temporal evolution was correlated with AMS $m / z 60$, which is typically associated with Levoglucosan known as a major molecular marker for fine particulate wood and biomass burning emissions (Alfarra et al., 2007; Schneider et al., 2006). Figure 9b/4 shows the temporal behavior of both mass concentrations which are correlated well $\left(R^{2}=0.9\right)$, supporting the identification of this factor. The WBOA diurnal pattern shows increased concentrations during the night until the late morning which decrease afterwards, likely due to a combination of domestic heating and boundary layer height cycles. However, WBOA concentrations are more dominant in the evening (Fig. 9c/4) similar to 
studies carried out in Zurich (Lanz et al., 2008). Maximum average values of the WBOA diurnal pattern at night probably result from domestic heating. Comparing the results for the different source regions the characteristic daily cycles of the four factors resemble each other, because independent of the source strengths in the individual air mass categories, effects like boundary layer height or temperature cycle, affect all air mass categories in the same way.

\subsubsection{Particulate organics in the different air mass types}

As discussed in Sect. 3.1 Fig. 5 depicts the average composition of NR-PM $\mathrm{PM}_{1}$ that belongs to the individual air mass categories. Here the total organic signal frames the average mass fractions of each of the OA components (OOA I, OOA II, HOA, WBOA) as well as the residuum in the green pie. The fractional contribution of the four components differs dependent on the air mass category. Nevertheless, lowvolatile OOA I can be found in each air mass type as the major submicron aerosol fraction besides all marine influenced air masses where sulfate plays the most important role (Sect. 3.3). Referred to the OA fraction OOA I is approximately in the same order (35\% in "Portugal + Marine" up to $49 \%$ in "Continental") in all air mass categories. The less aged OOA II component appears as second most abundant fraction of the OA in all air mass types with a contribution of approximately $25 \%$ beside the "Marine" category that has a lower OOA II fraction of $13 \%$. Over marine environments particle aging is a characteristic feature (Topping et al., 2004), resulting in a more oxygenated and a less volatile aerosol. In contrast, in continentally influenced air masses typically freshly produced biogenic and anthropogenic organic material exists, resulting in OOA II aerosol after photochemical processing. HOA concentrations are expected to be most prominent downwind of the urban city Huelva, however HOA aerosol undergoes rapid losses due to oxidation while it is transported (Zhang et al., 2007). Like in the studies of Zhang et al. (2007), we also found OOA concentrations similar or even enriched when the air was transported downwind of urban areas, likely due to condensation of vapors onto the pre-existing particles and oxidation of HOA, respectively. In contrast to all other air mass types, the "Marine" category contained HOA as the second most abundant organic aerosol component ( $25 \%$ of total OA) potentially originating from shipping emissions. In "Portugal + Huelva" air masses WBOA levels are more prominent and exceed HOA which is likewise the case for the city Zurich (Lanz et al., 2008). Due to the beginning of the winter season in the south of Spain with cooler temperatures and rain, domestic heating is an important contributor to this aerosol type as people heat using wood. This becomes apparent in increased WBOA concentrations especially in the evenings. In addition, as the measurement site is surrounded by pines and eucalyptus forests with agricultural activity WBOA average values around $7 \%$ in all continentally influenced air mass categories were measured.

\subsection{Meteorological conditions and ozone variability}

In order to evaluate ozone behavior it is necessary to understand the conditions and processes like the regional transport of ozone and its precursors, as well as, meteorological variables that have a significant influence on ozone production. To study the impact of meteorological conditions on ozone variability at the measurement site, wind speed and direction, temperature and relative humidity data were analyzed. The measured temperatures exhibit a characteristic diurnal cycle as expected (Fig. 10a) for the El Arenosillo location. The ozon mixing ratio is strongly associated with wind speed and direction as these meteorological parameters affect the transport and dispersion of ozone and its precursors (Adame et al., 2010). As indicated in Fig. 1, the wind blew mainly from the first, third and fourth quadrant and therefore air masses from Continental Europe and from the Atlantic Ocean arrive at the measurement station.

Using only the data from the "Continental" source region, we found a general characteristic daily ozone cycle in "El Arenosillo" that mainly follows this scheme (Fig. 10a):

- In the early morning hours minimum ozone levels exist around 07:00 UTC until ozon mixing ratios increase as photochemical reactions begin.

- Then, the ozone levels follow the intensity of the solar radiation with a delay of approximately $3 \mathrm{~h}$. Maximum ozon mixing ratios occur at approximately 15:00 UTC.

- When the solar radiation intensity decreases ozone levels also decrease and reach the lowest values at night (around 23:00 UTC) when the night inversion layer is present. Low nocturnal ozon mixing ratios are caused by the absence of ozone generation associated with insitu destruction of ozone, titration by NO and dry deposition (Adame et al., 2010).

This general pattern agrees with previous findings at coastal sites in the Southwest of the Iberian Peninsula in El Arenosillo (Adame et al., 2010a, b).

To study both, the diurnal variability of ozone and its association with various air masses, we display wind roses of ozon mixing ratios (showing the wind direction and speed dependence) around its concentration maximum (12:0016:00 UTC) and at night (21:00-06:00 UTC) in Fig. 10b and $\mathrm{c}$. The variability of ozone at this coastal measurement site depends both, on meteorological conditions (diurnal cycle of solar radiation and temperature) as well as on the transport of air masses with ozone precursors originating from different source regions. Maximum ozon mixing ratios $\left(47 \mathrm{nmol} \mathrm{mol}^{-1}\right)$ were reached in the afternoon around 15:00 UTC with largest levels in air masses coming from $\mathrm{NE}$ where ozone precursor substances (like $\mathrm{NO}_{\mathrm{x}}, \mathrm{CO}$ and 


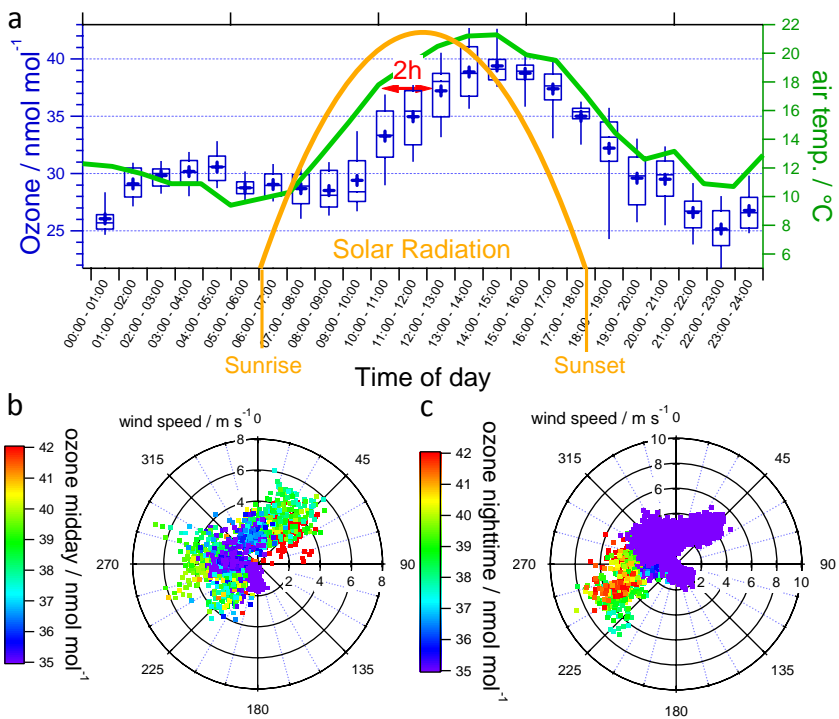

Fig. 10. Summary of the ozone variability at the measurement site. A general characteristic evolution of the daily ozone cycle for "El Arenosillo" using the "Continental" air mass category data is presented in (a). The temperature was measured using a meteorological station while solar radiation values are just for illustration. While ozone levels follow the solar radiation with a delay of approximately $3 \mathrm{~h}$, a delay of $2 \mathrm{~h}$ was registered relatively to the temperature trends. Wind roses (speed and direction) colored by the ozon mixing ratio at early afternoon (12:00-16:00 UTC) (b) and at night (21:00-06:00 UTC) (c) show that the ozone levels depend not only on the diurnal solar radiation cycle, but also on air mass origin associated with different precursor concentrations and composition.

VOC) from Seville have sufficient time to form ozone before arriving at the measurement site. During the nocturnal period, lowest ozon mixing ratios with values of about $23 \mathrm{nmol} \mathrm{mol}^{-1}$ were measured for this wind direction. A similar behavior but with smaller amplitude of the diurnal cycle is observed in "Continental" air masses. Due to the low number of data points from the "Seville" air mass category, the associated diurnal cycle is not well represented. Therefore, we show the diurnal cycle of the "Continental" air mass category in Fig. 10a. This source region is not as strongly affected by the transport of industrial and traffic emissions therefore midday ozon mixing ratios are lower $\left(39 \mathrm{nmol} \mathrm{mol}^{-1}\right)$ compared to "Seville" air masses. As a consequence of the absence of solar activity at night the ozon mixing ratios decrease to $25 \mathrm{nmol} \mathrm{mol}^{-1}$. Ozon mixing ratios in the NW wind direction are influenced by the strong urban pollution, including different types of emissions originating from Huelva. The wide spectrum of emissions leads to decreased ozone levels caused by titration by nitrogen oxides that are produced by industries and traffic. In contrast to the "Seville" category, the transport distance $(20 \mathrm{~km})$ for "Huelva" air masses to the station is not sufficient to allow the ozone precursor substances to generate ozone completely. Therefore ozon mixing ratios for this air mass type are low and vary between $36 \mathrm{nmol} \mathrm{mol}^{-1}$ at noon and $16 \mathrm{nmol} \mathrm{mol}^{-1}$ at night. Compared to all the other diurnal cycles discussed before, the ozone pattern is quite different in the "Marine" category (SW) where about $40 \mathrm{nmol} \mathrm{mol}^{-1} \mathrm{oc}-$ cur late at night (13:00 UTC). Interestingly, almost the same concentrations were measured during afternoon. We assume that no ozone destroying substances are available over marine environments.

\subsection{Inner- and inter-category variability}

The variability of particulate and trace gas concentrations and composition within the individual air mass categories has also been determined. This allows comparing the observed differences between air mass categories (inter-category variability) with the variability of the same parameters within the individual air masses (inner-category variability). The innercategory variability was determined as the relative standard deviation of the concentration values associated with the air mass in question. On the contrary, the inter-category variability was calculated as the relative standard deviation of the average concentrations of all air mass categories.

Generally, for most of the species the inner-category variability is larger than the inter-category variability. While for several parameters like organic aerosol concentrations (Table 2) or ozone both types of variability are very similar, only for nitrate larger differences are observed between the different air masses than within the individual air masses (Table 2). For the ozon mixing ratios the lowest variability was observed. While for total particle mass concentration and the concentrations of most of the secondary aerosol components (ammonium, sulfate, nitrate, OOA I) medium inner-category variability levels were observed, the largest variation in aerosol parameters was observed for the particle number concentrations as well as for the concentrations of black carbon, semi-volatile OOA (OOA II) and biomassburning related organic aerosol (WBOA). As an example, Fig. 11 shows the time series of the particle number concentration data for three different air masses ("Continental", "Marine + Huelva", "Marine). Standard deviations of the number concentrations represent the inner-category variability and show the large variations within the individual air mass categories, which exceed the differences between the various average values.

Significant differences from the above-mentioned general trends have been observed for several air quality parameters in some of the air mass categories. Extraordinary large inner-category variability for several parameters like black carbon, total and PMF-classified organics and particle number and mass concentrations have been observed for the marine influenced air mass categories. This is due to very low background concentrations that are interspersed with much larger concentrations in emission plumes, e.g. from individual ships. Contrary to this high variability, for ozone 


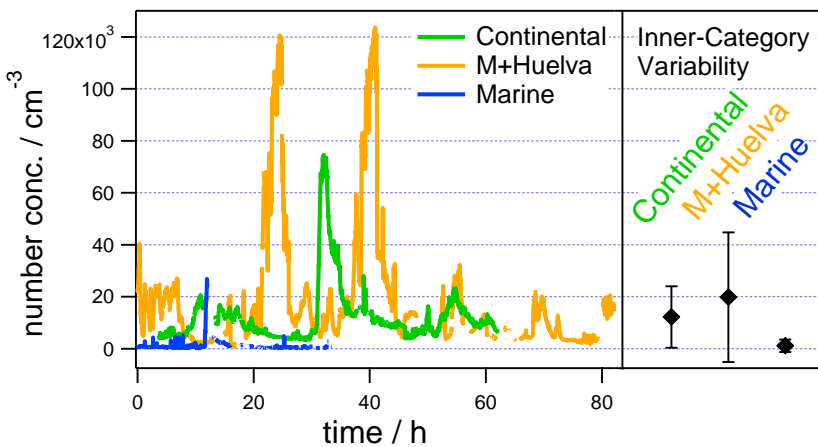

Fig. 11. Time series of the number concentration (CPC) for three different air masses ("Continental", "Marine + Huelva" and "Marine") and corresponding inner-category variability determined based on the relative standard deviations of the measured data.

the lowest inner-category variability is observed in the "Marine" category likely due to the wide absence of sources and sinks. Particularly low variability was observed for inorganic secondary species concentrations as well as particle number concentrations in the "Seville" and partially "Continental" air mass categories, likely associated with reasonably wellaged and mixed aerosol and low abundance of sources in the close vicinity of the measurement site.

\section{Discussion and summary}

The aim of our study is to evaluate typical values and the variability of aerosol, trace gas and meteorological parameters using measurements with the mobile laboratory (MoLa) at the interface of marine, urban and continentally influenced air masses in Southern Spain. This provides both, valuable information about the air composition in this part of Spain and how these parameters vary with air mass origin. To evaluate separate air masses with differentiated continental, urban and marine origin, the campaign was accomplished in winter. The advantage compared to summer measurements in this region is a well-defined origin of air masses with lower disturbances by intensive photochemistry and recirculation periods, which, additionally, affect the aerosol and trace gas phenomenology and therefore contribute to a more complex study scenario.

To provide the best possibility of studying the variability of air quality parameters with varying source regions, not only air mass trajectories but also local meteorology measured at the sampling site was used to classify different types of air masses. Although similar results were obtained from both methods, the classification made on basis of backwards trajectories is more conclusive compared to that using wind directions measured with the meteorological station. Consequently, using backwards trajectories six air mass types ("Seville", "Continental", "Portugal + Huelva", "Marine + Huelva", "Portugal + Marine", "Marine") were distin- guished and associated aerosol and trace gas parameters were further characterized.

Organics, sulfate and nitrate NR-PM $\mathrm{P}_{1}$ aerosol mass concentrations show the most significant variations and therefore they largely determine the chemical character of the aerosol from different source regions. While $64 \%$ of $\mathrm{PM}_{1}$ in "Continental" air masses consisted of organics, sulfate is the most abundant species in the "Marine" air mass category (54\%).

Like in the studies of Phinney et al. (2006) who identified sulfuric acid to be a dominant sulfate species in the marine environment, further analysis regarding the acidity show that in the "Marine" air mass type the species class "sulfate" is mainly composed of ammonium bisulfate (74\%) and sulfuric acid $(26 \%)$ as ammonium concentrations are significantly too low for sulfate neutralization. Similar as in the studies of Zorn et al. (2008) we also identified MSA in marine air masses, resulting from oxidized DMS that is released from phytoplankton. Nevertheless, it only contributes a minor degree to the total sulfate fraction (1\%). On the contrary, ammonia is more abundant in the terrestrial than in the marine boundary layer. Hence, sulfurous aerosols are mostly composed of ammonium bisulfate and ammonium sulfate in "Continental", "Marine + Huelva" and "Portugal + Marine" air masses.

As a result of a large number of industrial emission sources and road traffic in Huelva, nitrate is the major inorganic fraction of the aerosol composition in the "Portugal + Huelva" influenced air mass category. However, compared to a number of studies performed next to urban locations (DeCarlo et al., 2008; Stolzenburg and Hering, 2000; Salcedo et al., 2006), registered nitrate concentrations in this work are substantially lower. As reported in source apportionment studies in the Andalusian region, higher nitrate values were observed with increased influence of traffic (de la Rosa et al., 2010). As the number of registered cars in Huelva is low (Viana et al., 2007), this is a possible reason why in the corresponding air masses lower nitrate concentrations were measured.

The influence of air mass histories is reflected in average black carbon concentrations as well as in number and volume size distributions. Air masses originating from polluted Huelva and "Seville" source regions are associated with larger particle number concentrations and smaller particle sizes while lowest number concentration values with larger particle sizes are associated with "Marine" air mass types.

By using Positive Matrix Factorization (PMF) we showed that almost the entire organic aerosol can be categorized into one of the four classes OOA I, OOA II, HOA and WBOA. Our measurements show that OOA I is the most abundant submicron aerosol fraction in those air masses ("Seville", "Continental", "Portugal + Huelva") that have not been in contact with marine air masses where sulfate plays a more important role. As mentioned by Topping et al. (2004) over marine environments particle aging is a characteristic feature, thus the highly-oxygenated OOA I occurs also as major organic aerosol fraction in the "Marine" category. HOA was 
found as second most abundant organic aerosol fraction in this air mass type, possibly originating from ship emissions. In the "Seville", "Continental", "Marine + Huelva" and "Portugal + Marine" air mass categories, the less aged OOA II is the second dominant organic fraction. Although we have expected large HOA fractions in "Huelva" air mass categories, because urban areas are typically rich of HOA sources, only relatively low HOA levels have been observed, likely due to rapid losses of HOA that can result in decreased levels already at locations close to the emissions (Zhang et al., 2007). In addition, as traffic emissions are low due to the low number of registered cars in Huelva (Viana et al., 2007) HOA concentrations are probably reduced as well. Beside OOA I, WBOA occurs as a further dominant species in "Portugal + Huelva" air masses likely resulting from domestic heating. As people are using wood for heating purposes the wood burning source strength is becoming more apparent in the evening and night, in agreement with our findings of the WBOA cycle. Previous studies (Lanz et al., 2007; Zhang et al., 2005) observed prominent features of the HOA diurnal patterns around 08:00-13:00 UTC and 20:00 UTC from various anthropogenic activities. The diurnal variability of organic particle types can also be influenced by the solar radiation and temperature cycle. As OOA I reflects highly-aged processed OA, it only shows a weak photochemical dependence. In contrast, the temporal behavior of OOA II shows typical maximum concentrations at night as a consequence of accumulation of oxidized organic products in the vapor phase during day that condense onto particle surfaces at night like mentioned by Lanz et al. (2007).

Another main interest of our study was the investigation of ozon mixing ratios that depend on the solar radiation modified by precursor concentrations, chemical and physical processes and meteorological parameters. In agreement with previous findings at coastal sites (Adame et al., 2010a, b), a general characteristic daily ozone cycle was observed in the continental and urban air mass types. On the contrary, in marine air masses almost the same concentrations during day and night were registered, potentially due to the general absence of sources or sinks. Largest ozon mixing ratios were measured in the "Seville" category where ozone precursor substances had sufficient time to form ozone by photochemical reactions (Liu and Chan, 2002; Cremades et al., 2006) during the transport from Seville ( $70 \mathrm{~km}$ distance) to the site. Huelva air masses instead are characterized by lower ozon mixing ratios likely caused by titration of ozone by nitrogen oxides and transport times that were too short to allow the formation of ozone from precursors. Consequently, the registered maximum and minimum concentrations depend more on the source regions and source distances, the diurnal variability of ozone levels depends more on meteorological conditions (solar radiation/temperature).
The variability within and between the categories were calculated in order to compare the observed differences between the air mass categories with the variations within the individual air masses. Generally, for most of the species the inner-category variability is larger than the inter-category variability. Large inner-category variability for several parameters such as black carbon, PMF-classified organics and particle number and mass concentrations have been observed for marine influenced air masses, likely due to the generally very low background concentrations that are interspersed with much larger concentrations in emission plumes, e.g. from individual ships. Nitrate concentrations instead show the highest inner-category variability due to different kinds of source regions and their characteristic emission types. Generally, for most of the species the inner-category variability is larger than the inter-category variability, therefore the measured concentrations vary to a larger degree within the individual air masses than the average concentrations of the different air masses differ. Although the inner-category variability is often larger than the inter-category variability, which is calculated over the whole set of source categories, there are significant differences between individual categories for individual parameters.

In summary, the variability of the air composition associated with different source regions and distance from sources affects the particle loading, composition, size distributions and acidity as well as trace gas and meteorological parameters at a certain site. Additionally, the season has an important effect on the air composition and levels. Therefore, to provide a full characterization of the variability longtime measurements are required to study the characteristics, sources and processes in this part of Southern Europe where several different influences lead to a complex study scenario. However, in the context of this study an overview of typical air mass characteristics dependent on various source regions for this season can be obtained.

Acknowledgements. This research was supported by the DOMINO (Diel Oxidant Mechanisms In relation to Nitrogen Oxides) project, funded internally by the Max-Planck Society. The authors wish to acknowledge T. Böttger for technical support. Furthermore, we thank the INTA (National Institute for Aerospace Technology) for providing facilities at the measurement site. We gratefully acknowledge the NOAA Air Resources Laboratory (ARL) for the provision of the HYSPLIT transport and dispersion model (http://www.arl.noaa.gov/ready.html) used in this paper. J.-M. Diesch and S. R. Zorn also thank the German Research Foundation (DFG) for financing their work through the Research Training School GRK 826.

The service charges for this open access publication have been covered by the Max Planck Society.

Edited by: M. Kanakidou 


\section{References}

Adame, J. A., Lozano, A., Bolivar, J. P., De la Morena, B. A., Contreras, J., and Godoy, F.: Behavior, distribution and variability of surface ozone at an arid region in the south of Iberian Peninsula (Seville, Spain), Chemosphere, 70, 841-849, 2008.

Adame, J. A., Bolivar, J. P., and de la Morena, B. A.: Surface ozone measurements in the southwest of the Iberian Peninsula (Huelva, Spain), Environ. Sci. Pollut. R., 17, 355-368, 2010a.

Adame, J. A., Serrano, E., Bolivar, J. P., and de la Morena, B. A.: On the Tropospheric Ozone Variations in a Coastal Area of Southwestern Europe under a Mesoscale Circulation, J. Appl. Meteorol. Clim., 49, 748-759, 2010 b.

Alastuey, A., Querol, X., Plana, F., Viana, M., Ruiz, C. R., de la Campa, A. S., de la Rosa, J., Mantilla, E., and dos Santos, S. G.: Identification and chemical characterization of industrial particulate matter sources in southwest Spain, J. Air Waste Manage., 56, 993-1006, 2006.

Alfarra, M. R., Prevot, A. S. H., Szidat, S., Sandradewi, J., Weimer, S., Lanz, V. A., Schreiber, D., Mohr, M., and Baltensperger, U.: Identification of the mass spectral signature of organic aerosols from wood burning emissions, Environ. Sci. Technol., 41, 57705777, 2007.

Allan, J. D., Bower, K. N., Coe, H., Boudries, H., Jayne, J. T., Canagaratna, M. R., Millet, D. B., Goldstein, A. H., Quinn, P. K., Weber, R. J., and Worsnop, D. R.: Submicron aerosol composition at Trinidad Head, California, during ITCT 2K2: Its relationship with gas phase volatile organic carbon and assessment of instrument performance, J. Geophys. Res.-Atmos., 109, 16 pp., doi:10.1029/2003JD004208, 2004.

Allan, J. D., Baumgardner, D., Raga, G. B., Mayol-Bracero, O. L., Morales-García, F., García-García, F., Montero-Martínez, G., Borrmann, S., Schneider, J., Mertes, S., Walter, S., Gysel, M., Dusek, U., Frank, G. P., and Krämer, M.: Clouds and aerosols in Puerto Rico - a new evaluation, Atmos. Chem. Phys., 8, 12931309, doi:10.5194/acp-8-1293-2008, 2008.

Barnes, I., Hjorth, J., and Mihalopoulos, N.: Dimethyl sulfide and dimethyl sulfoxide and their oxidation in the atmosphere, Chem. Rev., 106, 940-975, 2006.

Benach, J., Yasui, Y., Borrell, C., Rosa, E., Pasarin, M. I., Benach, N., Espanol, E., Martinez, J. M., and Daponte, A.: Examining geographic patterns of mortality - The Atlas of mortality in small areas in Spain (1987-1995), Eur. J. Public Health, 13, 115-123, 2003.

Bouwman, A. F., Lee, D. S., Asman, W. A. H., Dentener, F. J., VanderHoek, K. W., and Olivier, J. G. J.: A global high-resolution emission inventory for ammonia, Global Biogeochem. Cy., 11, 561-587, 1997.

Buonanno, G., Stabile, L., Avino, P., and Vanoli, R.: Dimensional and chemical characterization of particles at a downwind receptor site of a waste-to-energy plant, Waste Manag., 30, 13251333, 2010.

Carretero, M. I., Bernabe, J. M., and Galan, E.: Mineralogy and origin of atmospheric particles in the industrial area of Huelva (SW Spain), Atmos. Environ., 39, 6777-6789, 2005.

Charlson, R. J., Lovelock, J. E., Andreae, M. O., and Warren, S. G.: Oceanic phytoplankton, atmospheric sulfur, cloud albedo and climate, Nature, 326, 655-661, 1987.

Coe, H., Allan, J. D., Alfarra, M. R., Bower, K. N., Flynn, M. J., McFiggans, G. B., Topping, D. O., Williams, P. I., O’Dowd,
C. D., Dall'Osto, M., Beddows, D. C. S., and Harrison, R. M.: Chemical and physical characteristics of aerosol particles at a remote coastal location, Mace Head, Ireland, during NAMBLEX, Atmos. Chem. Phys., 6, 3289-3301, doi:10.5194/acp-6-32892006, 2006.

Cremades, L. V., Toro, M. V., and Calbo, J.: Relationship between VOC and $\mathrm{NO}_{\mathrm{x}}$ emissions and chemical production of tropospheric ozone in the Aburra Valley (Colombia), Chemosphere, 65, 881-888, 2006.

CSIS: Segundo informe sobre Evaluacion Ambiental de la Ria de Huelva, available at: http://csis.es, 2002.

de la Campa, A. M. S., Pio, C., de la Rosa, J. D., Querol, X., Alastuey, A., and Gonzalez-Castanedo, Y.: Characterization and origin of EC and OC particulate matter near the Donana National Park (SW Spain), Environ. Res., 109, 671-681, 2009.

de la Campa, A. M. S., de la Rosa, J., Gonzalez-Castanedo, Y., Fernandez-Camacho, R., Alastuey, A., Querol, X., Stein, A. F., Ramos, J. L., Rodriguez, S., Orellana, I. G., and Nava, S.: Levels and chemical composition of PM in a city near a large $\mathrm{Cu}$-smelter in Spain, J. Environ. Monitor., 13, 1276-1287, 2011.

de la Rosa, J. D., de la Campa, A. M. S., Alastuey, A., Querol, X., Gonzalez-Castanedo, Y., Fernandez-Camacho, R., and Stein, A. F.: Using $\mathrm{PM}(10)$ geochemical maps for defining the origin of atmospheric pollution in Andalusia (Southern Spain), Atmos. Environ., 44, 4595-4605, 2010.

DeCarlo, P. F., Kimmel, J. R., Trimborn, A., Northway, M. J., Jayne, J. T., Aiken, A. C., Gonin, M., Fuhrer, K., Horvath, T., Docherty, K. S., Worsnop, D. R., and Jimenez, J. L.: Field-deployable, high-resolution, time-of-flight aerosol mass spectrometer, Anal. Chem., 78, 8281-8289, 2006.

DeCarlo, P. F., Dunlea, E. J., Kimmel, J. R., Aiken, A. C., Sueper, D., Crounse, J., Wennberg, P. O., Emmons, L., Shinozuka, Y., Clarke, A., Zhou, J., Tomlinson, J., Collins, D. R., Knapp, D., Weinheimer, A. J., Montzka, D. D., Campos, T., and Jimenez, J. L.: Fast airborne aerosol size and chemistry measurements above Mexico City and Central Mexico during the MILAGRO campaign, Atmos. Chem. Phys., 8, 4027-4048, doi:10.5194/acp8-4027-2008, 2008.

Draxler, R. R. and Rolph, G. D.: HYSPLIT (Hybrid Single-Particle Lagrangian Integrated Trajectory), NOAA Air Resources Laboratory, Silver Spring, MD, Model access via NOAA ARL READY Website (http://www.arl.noaa.gov/ready/hysplit4.html), 2003.

Drewnick, F., Hings, S. S., Alfarra, M. R., Prevot, A. S. H., and Borrmann, S.: Aerosol quantification with the Aerodyne Aerosol Mass Spectrometer: detection limits and ionizer background effects, Atmos. Meas. Tech., 2, 33-46, doi:10.5194/amt-2-332009, 2009.

Drewnick, F., Böttger, T., von der Weiden-Reinmüller, S.-L., Zorn, S. R., Klimach, T., Schneider, J., and Borrmann, S.: Design of a mobile aerosol research laboratory and data processing tools for effective stationary and mobile field measurements, Atmos. Meas. Tech. Discuss., 5, 2273-2313, doi:10.5194/amtd-5-22732012, 2012.

Fernández-Camacho, R., de la Rosa, J., de la Campa, A. M. S., Gonzalez-Castanedo, Y., Alastuey, A., Querol, X., and Rodriguez, S.: Geochemical characterization of $\mathrm{Cu}$-smelter emission plumes with impact in an urban area of SW Spain, Atmos. Res., 96, 590-601, 2010a. 
Fernández-Camacho, R., Rodríguez, S., de la Rosa, J., Sánchez de la Campa, A. M., Viana, M., Alastuey, A., and Querol, X.: Ultrafine particle formation in the inland sea breeze airflow in Southwest Europe, Atmos. Chem. Phys., 10, 9615-9630, doi:10.5194/acp-10-9615-2010, 2010b.

Hock, N., Schneider, J., Borrmann, S., Römpp, A., Moortgat, G., Franze, T., Schauer, C., Pöschl, U., Plass-Dülmer, C., and Berresheim, H.: Rural continental aerosol properties and processes observed during the Hohenpeissenberg Aerosol Characterization Experiment (HAZE2002), Atmos. Chem. Phys., 8, 603-623, doi:10.5194/acp-8-603-2008, 2008.

Huffman, J. A., Jayne, J. T., Drewnick, F., Aiken, A. C., Onasch, T., Worsnop, D. R., and Jimenez, J. L.: Design, modeling, optimization, and experimental tests of a particle beam width probe for the aerodyne aerosol mass spectrometer, Aerosol Sci. Technol., 39, 1143-1163, 2005.

IPCC: Climate Change 2007: The Physical Science Basis. Contribution of Working Group I to the Fourth Assessment Report of the Intergovernmental Panel on Climate Change, edited by: Solomon, S., Qin, D., Manning, M., Chen, Z., Marquis, M., Averyt, K. B., Tignor, M., and Miller, H. L., Cambridge University Press, Cambridge, UK and New York, NY, USA, 996 pp., 2007.

Jickells, T. D., Kelly, S. D., Baker, A. R., Biswas, K., Dennis, P. F., Spokes, L. J., Witt, M., and Yeatman, S. G.: Isotopic evidence for a marine ammonia source, Geophys. Res. Lett., 30, 4 pp., doi:10.1029/2002g1016728, 2003.

Lanz, V. A., Alfarra, M. R., Baltensperger, U., Buchmann, B., Hueglin, C., and Prévôt, A. S. H.: Source apportionment of submicron organic aerosols at an urban site by factor analytical modelling of aerosol mass spectra, Atmos. Chem. Phys., 7, 1503-1522, doi:10.5194/acp-7-1503-2007, 2007.

Lanz, V. A., Alfarra, M. R., Baltensperger, U., Buchmann, B., Hueglin, C., Szidat, S., Wehrli, M. N., Wacker, L., Weimer, S., Caseiro, A., Puxbaum, H., and Prevot, A. S. H.: Source attribution of submicron organic aerosols during wintertime inversions by advanced factor analysis of aerosol mass spectra, Environ. Sci. Technol., 42, 214-220, 2008.

Liu, H. P. and Chan, J. C. L.: An investigation of air-pollutant patterns under sea-land breezes during a severe air-pollution episode in Hong Kong, Atmos. Environ., 36, 591-601, 2002.

Paatero, P.: Least squares formulation of robust non-negative factor analysis, Chemometr. Intell. Lab., 37, 23-35, 1997.

Paatero, P. and Tapper, U.: Positive matrix factorization - a nonnegative factor model with optimal utilization of error-estimates of data values, Environmetrics, 5, 111-126, 1994.

Perez-Lopez, R., Nieto, J. M., Lopez-Coto, I., Aguado, J. L., Bolivar, J. P., and Santisteban, M.: Dynamics of contaminants in phosphogypsum of the fertilizer industry of Huelva (SW Spain): From phosphate rock ore to the environment, Appl. Geochem., 25, 705-715, 2010.

Pey, J., Querol, X., de la Rosa, J., Gonzalez-Castanedo, Y., Alastuey, A., Gangoiti, G., de la Campa, A. S., AladosArboledas, L., Sorribas, M., Pio, C., Cachorro, V., Pineiro, M., Lopez-Mahia, P., and Garcia-Gacio, D.: Characterization of a long range transport pollution episode affecting PM in SW Spain, J. Environ. Monitor., 10, 1158-1171, 2008.

Phinney, L., Leaitch, W. R., Lohmann, U., Boudries, H., Worsnop, D. R., Jayne, J. T., Toom-Sauntry, D., Wadleigh, M., Sharma, S., and Shantz, N.: Characterization of the aerosol over the sub- arctic north east Pacific Ocean, Deep-Sea Res. Pt. II, 53, 24102433, 2006.

Pope, C. A. and Dockery, D. W.: Health effects of fine particulate air pollution: Lines that connect, J. Air Waste Manage., 56, 709742, 2006.

Querol, X., Alastuey, A., de la Rosa, J., Sanchez-de-la-Campa, A., Plana, F., and Ruiz, C. R.: Source apportionment analysis of atmospheric particulates in an industrialised urban site in southwestern Spain, Atmos. Environ., 36, 3113-3125, 2002.

Querol, X., Alastuey, A., Rodriguez, S., Viana, M. M., Artinano, B., Salvador, P., Mantilla, E., do Santos, S. G., Patier, R. F., de La Rosa, J., de la Campa, A. S., Menendez, M., and Gil, J. J.: Levels of particulate matter in rural, urban and industrial sites in Spain, Sci. Total Environ., 334, 359-376, 2004.

Querol, X., Alastuey, A., Pey, J., Cusack, M., Pérez, N., Mihalopoulos, N., Theodosi, C., Gerasopoulos, E., Kubilay, N., and Koçak, M.: Variability in regional background aerosols within the Mediterranean, Atmos. Chem. Phys., 9, 4575-4591, doi:10.5194/acp-9-4575-2009, 2009.

Salcedo, D., Onasch, T. B., Dzepina, K., Canagaratna, M. R., Zhang, Q., Huffman, J. A., DeCarlo, P. F., Jayne, J. T., Mortimer, P., Worsnop, D. R., Kolb, C. E., Johnson, K. S., Zuberi, B., Marr, L. C., Volkamer, R., Molina, L. T., Molina, M. J., Cardenas, B., Bernabé, R. M., Márquez, C., Gaffney, J. S., Marley, N. A., Laskin, A., Shutthanandan, V., Xie, Y., Brune, W., Lesher, R., Shirley, T., and Jimenez, J. L.: Characterization of ambient aerosols in Mexico City during the MCMA-2003 campaign with Aerosol Mass Spectrometry: results from the CENICA Supersite, Atmos. Chem. Phys., 6, 925-946, doi:10.5194/acp-6-9252006, 2006.

Sanchez de la Campa, A. M., de la Rosa, J., Querol, X., Alastuey, A., and Mantilla, E.: Geochemistry and origin of $\mathrm{PM}_{10}$ in the Huelva region, Southwestern Spain, Environ. Res., 103, 305316, 2007.

Schneider, J., Weimer, S., Drewnick, F., Borrmann, S., Helas, G., Gwaze, P., Schmid, O., Andreae, M. O., and Kirchner, U.: Mass spectrometric analysis and aerodynamic properties of various types of combustion-related aerosol particles, Int. J. Mass Spectrom., 258, 37-49, 2006.

Stolzenburg, M. R. and Hering, S. V.: Method for the automated measurement of fine particle nitrate in the atmosphere, Environ. Sci. Technol., 34, 907-914, 2000.

Sun, J. Y., Zhang, Q., Canagaratna, M. R., Zhang, Y. M., Ng, N. L., Sun, Y. L., Jayne, J. T., Zhang, X. C., Zhang, X. Y., and Worsnop, D. R.: Highly time- and size-resolved characterization of submicron aerosol particles in Beijing using an Aerodyne Aerosol Mass Spectrometer, Atmos. Environ., 44, 131-140, 2010.

Takami, A., Miyoshi, T., Shimono, A., and Hatakeyama, S.: Chemical composition of fine aerosol measured by AMS at Fukue Island, Japan during APEX period, Atmos. Environ., 39, 49134924, 2005.

Toledano, C., Cachorro, V. E., de Frutos, A. M., Torres, B., Berjón, A., Sorribas, M., and Stone, R. S.: Airmass Classification and Analysis of Aerosol Types at El Arenosillo (Spain), J. Appl. Meteorol. Clim., 48, 962-981, 2009.

Topping, D., Coe, H., McFiggans, G., Burgess, R., Allan, J., Alfarra, M. R., Bower, K., Choularton, T. W., Decesari, S., and Facchini, M. C.: Aerosol chemical characteristics from sampling conducted on the Island of Jeju, Korea during ACE Asia, Atmos. 
Environ., 38, 2111-2123, 2004.

Ulbrich, I. M., Canagaratna, M. R., Zhang, Q., Worsnop, D. R., and Jimenez, J. L.: Interpretation of organic components from Positive Matrix Factorization of aerosol mass spectrometric data, Atmos. Chem. Phys., 9, 2891-2918, doi:10.5194/acp-9-2891-2009, 2009.

Viana, M., Querol, X., Gotschi, T., Alastuey, A., Sunyer, J., Forsberg, B., Heinrich, J., Norback, D., Payo, F., Maldonado, J. A., and Kunzli, N.: Source apportionment of ambient $\mathrm{PM}_{2.5}$ at five Spanish centres of the European Community Respiratory Health Survey (ECRHS II), Atmos. Environ., 41, 1395-1406, 2007.

von der Weiden, S.-L., Drewnick, F., and Borrmann, S.: Particle Loss Calculator - a new software tool for the assessment of the performance of aerosol inlet systems, Atmos. Meas. Tech., 2, 479-494, doi:10.5194/amt-2-479-2009, 2009.
Warneck, P.: Chemistry of the natural atmosphere, in: International geophysics series, Academic Press Inc., 1988.

Zhang, Q., Alfarra, M. R., Worsnop, D. R., Allan, J. D., Coe, H., Canagaratna, M. R., and Jimenez, J. L.: Deconvolution and quantification of hydrocarbon-like and oxygenated organic aerosols based on aerosol mass spectrometry, Environ. Sci. Technol., 39, 4938-4952, 2005.

Zhang, Q., Jimenez, J. L., Worsnop, D. R., and Canagaratna, M.: A case study of urban particle acidity and its influence on secondary organic aerosol, Environ. Sci. Technol., 41, 3213-3219, 2007.

Zorn, S. R., Drewnick, F., Schott, M., Hoffmann, T., and Borrmann, S.: Characterization of the South Atlantic marine boundary layer aerosol using an aerodyne aerosol mass spectrometer, Atmos. Chem. Phys., 8, 4711-4728, doi:10.5194/acp-8-47112008, 2008. 